\title{
Debonding Failure Analysis of Reinforced Concrete Beams Strengthened with CFRP Plates
}

\author{
Rendy Thamrin * ${ }^{\mathbb{D}}$, Zaidir Zaidir and Silvy Desharma
}

check for updates

Citation: Thamrin, R.; Zaidir, Z.; Desharma, S. Debonding Failure Analysis of Reinforced Concrete Beams Strengthened with CFRP Plates. Polymers 2021, 13, 2738. https://doi.org/10.3390/ polym 13162738

Academic Editor: Enzo Martinelli

Received: 8 July 2021

Accepted: 4 August 2021

Published: 16 August 2021

Publisher's Note: MDPI stays neutral with regard to jurisdictional claims in published maps and institutional affiliations.

Copyright: (c) 2021 by the authors. Licensee MDPI, Basel, Switzerland. This article is an open access article distributed under the terms and conditions of the Creative Commons Attribution (CC BY) license (https:/ / creativecommons.org/licenses/by/ $4.0 /)$.
Department of Civil Engineering, Faculty of Engineering, Andalas University,

Padang 25163, West Sumatera, Indonesia; zaidir2000@yahoo.com (Z.Z.); sydesharma@gmail.com (S.D.)

* Correspondence: rendythamrin@eng.unand.ac.id

\begin{abstract}
In this study, experimental work was carried out on reinforced concrete (RC) beams strengthened with carbon fiber reinforced polymers (CFRP) plates. This study aims to examine the effect of the reinforcement ratio on the flexural behavior of these beams and propose a new model for predicting the debonding moment. Six RC beams consisting of three control beams and three beams strengthened with CFRP plates were tested. The beams were simply supported and loaded with four-point bending. The test variable was the tensile reinforcement ratio $(1 \%, 1.5 \%$, and $2.5 \%$ ). Analytical prediction using the fiber element method was also carried out to obtain the complete theoretical response of the beam due to flexural loads. The test results show that the reinforcement ratio affected the bending performance of RC beams with CFRP plates. Following this, the experimental data from 60 beam test results from published literature and this study were analyzed. From these data, it was found that the ratio of tensile reinforcement, the ratio of modulus of elasticity of concrete, the modulus of elasticity of the plate, and plate thickness all affect the value of debonding moment. A parametric study using fiber elements and the two-dimensional finite element method was also carried out to confirm the effect of these variables on debonding failure. These variables were then used to develop an equation to predict the debonding moment of RC beams strengthened with CFRP plates, using simple statistical analysis. This analysis resulted in a simple model for predicting the debonding moment. Then the model is entered into a computer program, and the complete response of the cross-section due to debonding failure can be obtained.
\end{abstract}

Keywords: debonding load; CFRP plate; RC beams; flexural strengthening; simple statistical analysis; fiber element method

\section{Introduction}

Buildings that experience deterioration in strength, damage, or changes in the design code during their service lifetime need to be strengthened or repaired to meet design code specifications. One way to do this is to use externally bonded Carbon Fiber Reinforced Polymer (CFRP) plates. These have been extensively researched and used to increase the bending capacity of reinforced concrete structures for more than three decades and are reported to have shown promising results [1-20]. This strengthening method is practical and easy to implement and has other advantages such as corrosion resistance, high relative stiffness, and light weight [2,3,6,7].

Experimental studies of externally strengthened RC beams with CFRP plates that several previous researchers have carried out showed premature failure indicated by the loss of the bond between the concrete and the CFRP plate [1-17]. The loss of this bond may or may not result in a separation of the concrete cover layer. Therefore, the capacity of the beam strengthened with CFRP plates is limited to avoid this debonding failure [8]. This limitation means that a large part of the CFRP plate's capacity to carry the load is unused. As a result, only about $20-30 \%$ of the overall capacity of the CFRP plate can be used in the strengthened concrete beam [20]. 
Previous research has shown that the capacity of a beam strengthened with CFRP plates is influenced by several variables, including the tensile reinforcement ratio [6], the thickness of the CFRP plate $[15,18]$, the modulus of elasticity of CFRP plate [18], and the compressive strength of concrete $[18,19]$. Nguyen et al. [6] conducted a study on the effect of the reinforcement ratio on the flexural capacity of reinforced concrete beams with CFRP plates, comparing over-reinforced beams and under-reinforced beams. The results showed that the increase in the flexural capacity of over-reinforced beams was smaller than that of under-reinforced beams.

The effect of variations in the CFRP plate layer on reinforced concrete beams was demonstrated in the study by Ahmed et al. [15]. Those studies indicate that the load capacity increases with the number of layers of CFRP plates on the tensile surface of the beam. In a study conducted by Sayed [18], the thickness of the FRP plate (tf) had an effect on the ultimate bond strength of $\mathrm{tf}$ to the power of $0.41\left(\mathrm{t}_{\mathrm{f}}{ }^{0.41}\right)$ when the attachment length of the plate was less than the effective attachment length, and tf to the power of $0.32\left(t_{f}{ }^{0.32}\right)$ when the attachment length was more significant than the effective attachment length.

The effect of the modulus of elasticity of the FRP plate (Ef) on the ultimate bond strength was studied by Sayed [18]. Sayed found that the effect was Ef to the power of 0.34 when the attachment length was less than the effective attachment length, and Ef to the power of 0.59 when the attachment length was more significant than the effective attachment length. Sayed [18] also found that the ultimate bond load capacity of FRP plates in concrete increased by $f c^{\prime}$ to the power of 0.34 due to the influence of the compressive strength of the concrete $\left(f \mathcal{c}^{\prime}\right)$. In another study, Mansour [19] showed that the compressive strength of concrete affects the load capacity of reinforced concrete beams strengthened with FRP plates, where the load capacity increases along with the increase in the compressive strength of the concrete.

In previous studies, models for predicting flexural debonding moment in FRP-plated reinforced concrete beams were proposed by Oehlers [21] and Teng and Chen [22]. Oehlers [21] formulated an empirical equation to predict the flexural debonding moment, which is influenced by: the elastic modulus of the concrete, the elastic modulus of the FRP, the cracked second moment of the area of the plated section, the cylinder splitting tensile strength of concrete, and the thickness of the FRP plate. The equation proposed by Teng and Chen [22] was influenced by the theoretical ultimate moment of the unplated section, which is also the upper bound of the flexural debonding moment, the flexural rigidities of the cracked section with and without an FRP plate, the elastic modulus of the FRP, the thickness and width of the FRP plate, the elastic modulus of the concrete, and the width and effective depth of the RC beam.

This present study examines the effect of the reinforcement ratio on the flexural behavior of RC beams with CFRP plates and proposes a model for calculating the debonding moment. In this work, data from previously published studies regarding the flexural strengthening of reinforced concrete beams by externally attaching CFRP plates to the tensile surface were collected, providing a database of 60 experimental beam test results from 17 studies. These were analyzed to achieve the objectives of this study. Cross-sectional analysis based on theoretical moment-curvature determination was also carried out to theoretically predict the flexural capacity of CFRP-plated RC beams. The calculation process was supported by a computer program called Reinforced Concrete Cross Section Analysis (RCCSA) [23-25]. The moment-curvature relationship obtained from the analysis can then be used to obtain a complete response of the load-deflection relationship. Then, the proposed debonding moment model is entered into a computer program, and a full response from the cross-section due to debonding failure can be obtained. The analytical results were then compared with those obtained from laboratory testing.

\section{Experimental Study}

The study by Thamrin et al. [1] consisted of six concrete beams, three of which were reinforced with a tensile longitudinal reinforcement ratio of $1 \%, 1.5 \%$, or $2.5 \%$. The beams 
tested were classified into control beams (G6C1, G6C2, and G6C3) and beams strengthened with CFRP plates (G6P1, G6P2, and G6P3). The cross-section of each of the beams was $125 \times 250 \mathrm{~mm}$, and each had an effective depth of $230 \mathrm{~mm}$. The beams were simply supported and had a length of $2000 \mathrm{~mm}$ with an overhang of $150 \mathrm{~mm}$ on each side; hence the total size of the beam was $2300 \mathrm{~mm}$, as shown in Figure 1.

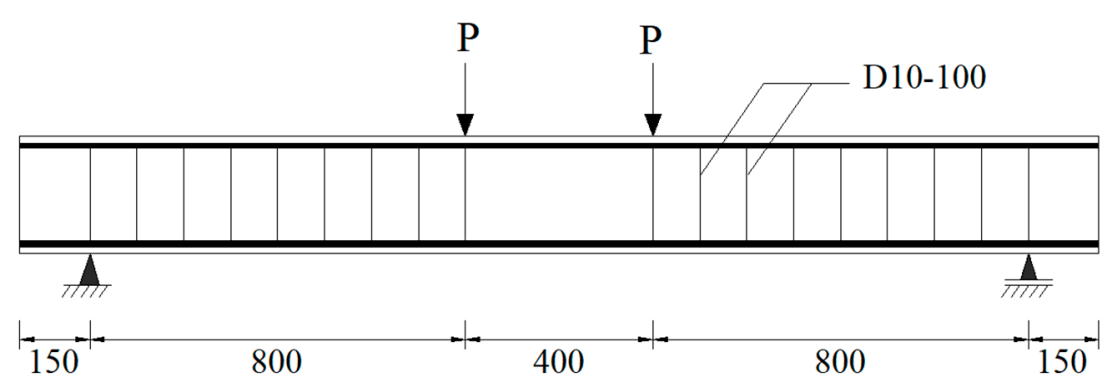

(a)

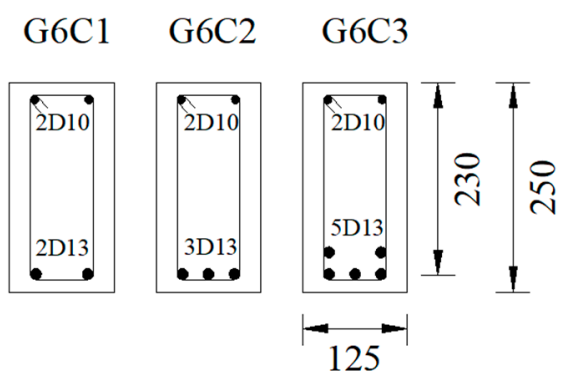

(b)

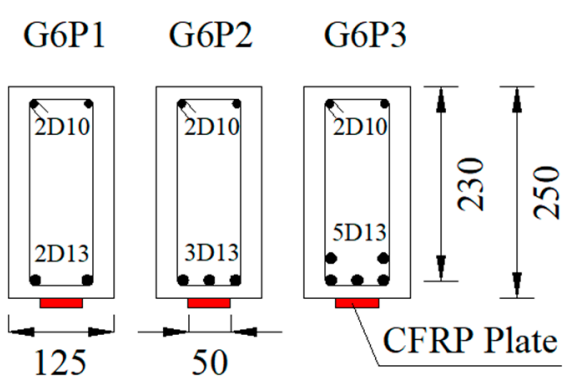

(c)

Figure 1. Schematic pictures of the tested beams and their identifications (a) beam dimension and loading position, (b) cross section of control beams, and (c) cross section of plated beams.

The compressive and transverse reinforcement for all beams were $10 \mathrm{~mm}$ diameter bars with a yield strength of $355 \mathrm{MPa}$. The tensile reinforcement used in the test specimens had a $13 \mathrm{~mm}$ diameter and a yield strength of $448 \mathrm{MPa}$. Closed type transverse reinforcement with $100 \mathrm{~mm}$ spacing was used on all tested beams to avoid premature collapse due to shear forces. A ready-mix company supplied the fresh concrete, and the compressive strength of the concrete at the age of 28 days was $20 \mathrm{MPa}$.

The CFRP plates used were obtained from a roll of Tyfo ${ }^{\circledR}$ UC Composite Laminate Strip laminated by FYFE Co. LLC, USA. The CFRP plates were $1.9 \mathrm{~mm}$ thick and $50 \mathrm{~mm}$ wide. CFRP plates were glued to the tension face of the strengthened beams with epoxy adhesive by FYFE Co. LLC, as shown in Figures 1c and 2. Tyfo ${ }^{\circledR}$ S Epoxy was applied as the main layer on the prepared concrete substrate and Tyfo ${ }^{\circledR}$ TC Epoxy was applied to a thickness of $2 \mathrm{~mm}$ on the substrate before applying the CFRP plate. Installation of CFRP plates on beams was carried out by certified applicators, as shown in Figure 2. The mechanical properties of the CFRP plate used were supplied by the manufacturer. The ultimate tensile strength in primary fiber direction and tensile modulus of the CFRP plates used were 2.51 GPa and $139 \mathrm{GPa}$, respectively.

Testing of simply supported beams was carried out by applying two concentrated loads $400 \mathrm{~mm}$ apart. The load was applied by a $500 \mathrm{kN}$ capacity of a hydraulic actuator. Load cell and linear variable displacement transducers (LVDTs) were used to measure the deflection of the beams. Load cell and LVDT's were connected to a data acquisition system, and the data was collected on data media. The deflections of the beam located at three positions were recorded continuously. In each test, the load was gradually increased until collapse occurred. Test setup, the position of the load, and LVDT's on the tested beam are shown in Figure 3. The load cell, LVDT's and data logger used were products of Tokyo Measuring Instruments Laboratory Co., Ltd., Tokyo, Japan. 


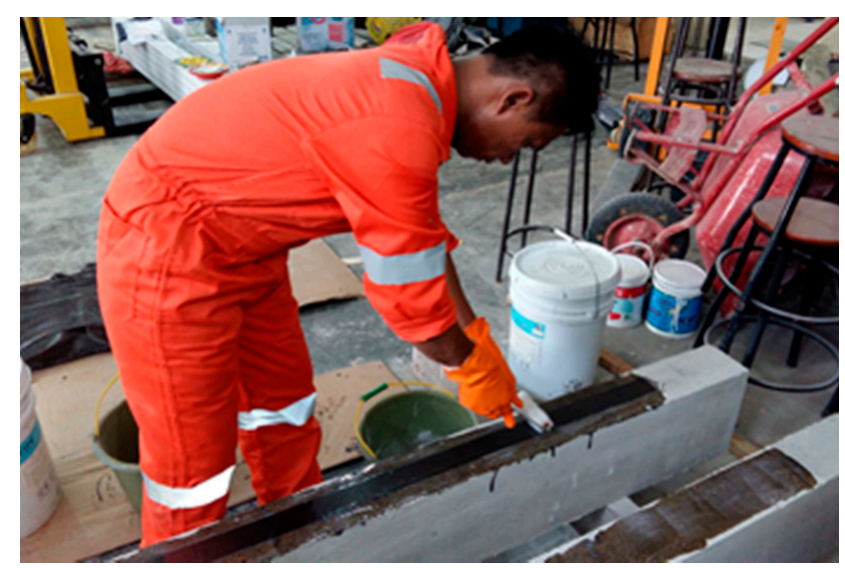

Figure 2. Installing the CFRP plate at the bottom of the beam.

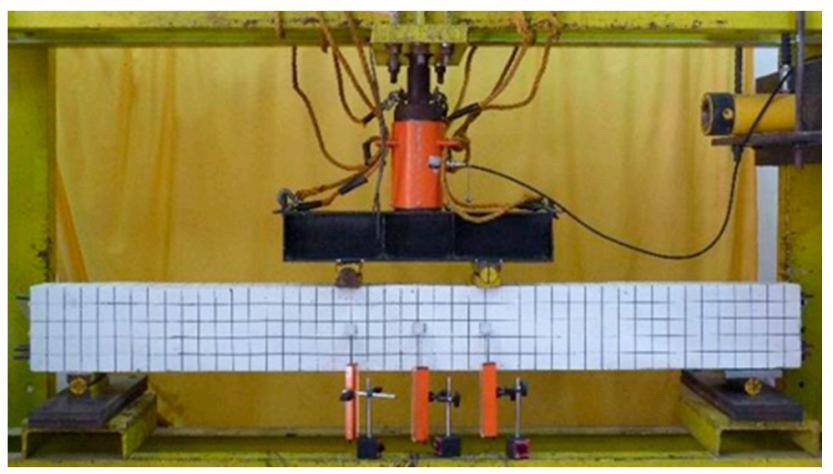

Figure 3. Test setup and equipment used.

\section{Fiber Element Method}

Flexural analysis of the reinforced concrete cross-section using the fiber element method was carried out to obtain the complete flexural response of the cross-section with CFRP plates due to the applied bending moment. Figure 4 shows the analytical model of the fiber element method. Strain compatibility in this method was applied using the assumption of a perfect bond between concrete and the steel reinforcement as well as between concrete and the CFRP plates. Linear strain was assumed for strain distribution along with the beam depth. The appropriate stress state at each strain position during the calculation process must follow the stress-strain equation of materials. Therefore, the assumed stress-strain relationship for concrete, steel, and the CFRP plate was applied. A bilinear stress-strain model for steel bars and a linear model for the CFRP plate were used. The parabolic stress-strain model for concrete in compression was adopted from the literature [26].

The magnitude of the internal forces was then obtained by using the corresponding strain $(\varepsilon i, \varepsilon s i$, and $\varepsilon p)$ and stress level at each incremental curvature $(\varphi)$ and the equilibrium of the plated cross-section was determined by an iterative process. Once the equilibrium conditions for the cross-section were fulfilled, the moment at the corresponding curvature was calculated by multiplying the internal forces with the corresponding moment arms (yi). Then the calculation process was repeated until the maximum compressive strain of $\varepsilon c m=0.003$ was reached.

The first step of this method is performed by dividing the cross-section into a finite number of reinforcement and concrete layers, as illustrated in Figure 4. The steel plate is assumed to be the reinforcement layer in the analytical model, and connections between reinforcement layers and concrete layers are assumed to be perfectly bonded. Hence, the strain distribution along the beam cross-section height can be considered linear, as shown in Figure 4. 


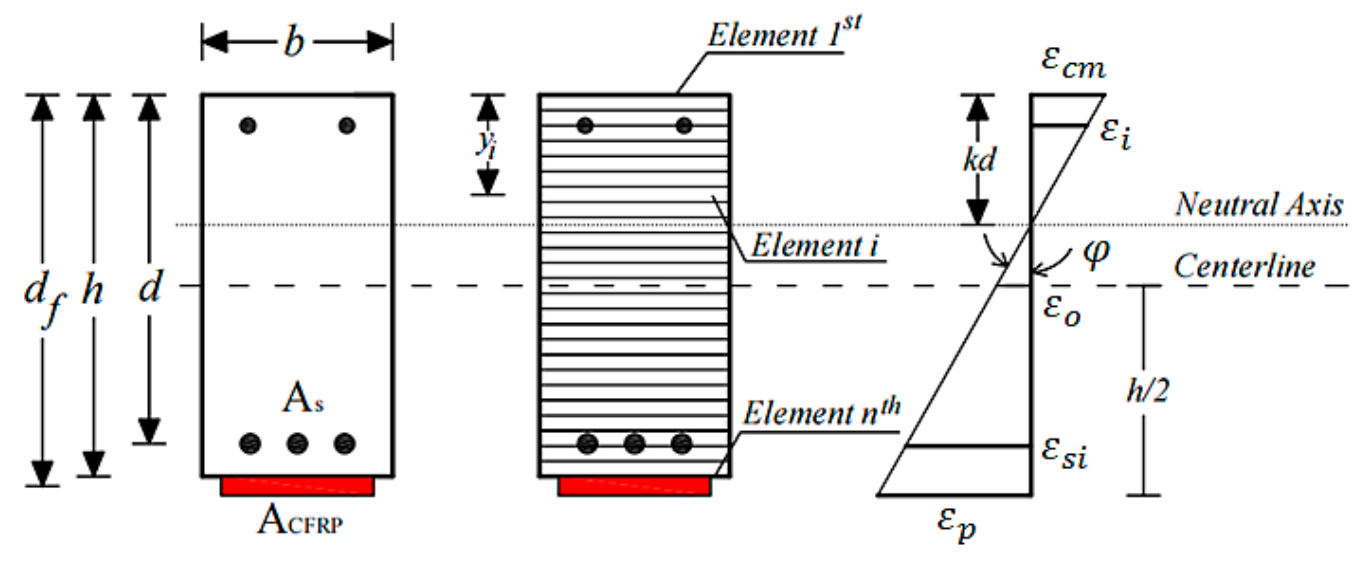

(a)

(b)

(c)

Figure 4. Analytical model using the fiber element method (a) reinforced concrete cross section, (b) fiber element model, and (c) strain distribution.

The strain, $\varepsilon_{i}$, in the concrete and reinforcement elements for an assumed value of curvature, $\varphi$, and the lever arm of each element, $y_{i}$, can be calculated as:

$$
\varepsilon_{i}=\varepsilon_{o}-\left(\varphi y_{i}\right)
$$

The second step is calculating the stresses using a given stress-strain equation for concrete and steel. The stresses, $\sigma_{i}$, acting on each reinforcement layer, concrete element and the steel plate can be determined as:

$$
\sigma_{i}=f\left(\varepsilon_{i}\right)
$$

The stress-strain equation for concrete in compression applied in this study is adopted from the model proposed by Mander et al. [26]. For concrete in tension, a linear model is used up to the maximum concrete tensile strength without a tension stiffening effect. The stress-strain equation for steel bars and steel plates used in this study is based on a bilinear model.

The third step is calculating the internal forces, $F_{i}$, for each of the concrete elements and reinforcement layers with an area, $A_{i}$, using:

$$
F_{i}=A_{i} \sigma_{i}
$$

The fourth step is checking whether the equilibrium of internal forces is satisfied. An iterative procedure is required to obtain the value of axial strain, $\varepsilon_{0}$, which fulfills the equilibrium condition of the internal forces.

The fifth step is calculating the internal moment, $M$, in the cross-section as:

$$
M=\Sigma F_{i} y_{i}
$$

The last step is calculating the load, $P$, and deflection, $\delta$, values by using the appropriate moment and curvature distribution with each incremental step along the length, $L$, of the beam, which is calculated as:

$$
\delta=\int_{0}^{\frac{L}{2}} x \varphi d x
$$

The complete details of the computation procedure can be found in the literature $[24,25]$. The algorithm of the computation procedure is illustrated in Figure 5. A computer program based on the formula above was developed and used to facilitate this process [23-25]. 


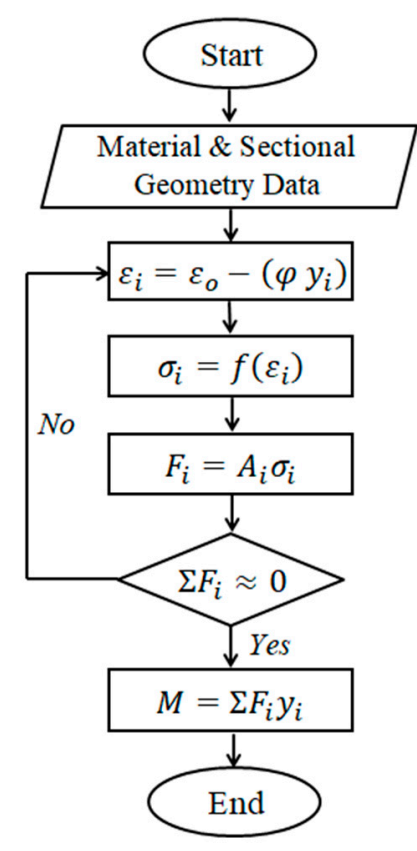

Figure 5. The algorithm of the computation procedure.

\section{Finite Element Method}

The finite element method was used in this study to analyze the strain behavior of beams in the shear span zone and the load-deflection curves. The 2D ATENA software was used to accomplish this purpose. ATENA is finite element-based software specially designed for reinforced concrete analysis, and a complete explanation of this software can be seen in the literature [27]. The beam model analyzed with ATENA software will be discussed in more detail later. The beam is modeled with a $40 \mathrm{~mm}$ quadrilateral element, as shown in Figure 6. Only half of the beam length was used in the finite element model because of the symmetry of the beam's two-point loads position and geometry. The axes of symmetry in the middle of the beam was simulated by boundary conditions with constraints on horizontal displacement. As in the laboratory test, the acting forces and supports are applied through the steel plate to avoid stress concentrations to the concrete. The load applied to the beam was a load case with prescribed deformations type and the displacement given was $0.1 \mathrm{~mm}$ downward.

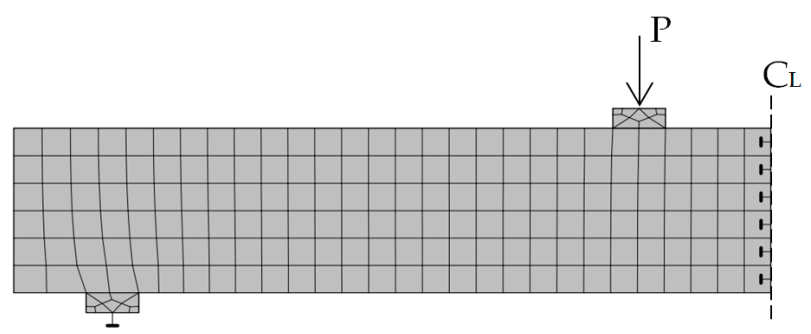

Figure 6. Finite element model of beam specimen using ATENA 2D.

The plates were assumed to be perfectly bonded to the concrete. Stress-strain models for concrete, reinforcing steel, steel plates, and CFRP plates used the material models available in the ATENA software. The SBETA material model was used for concrete and the bilinear model was used for the steel reinforcement. The loading and support steel plates were modeled as an elastic material, while the CFRP plate was modeled as reinforcement with elastic material. Stress-strain models used in the finite element analysis are shown in Figure 7. 


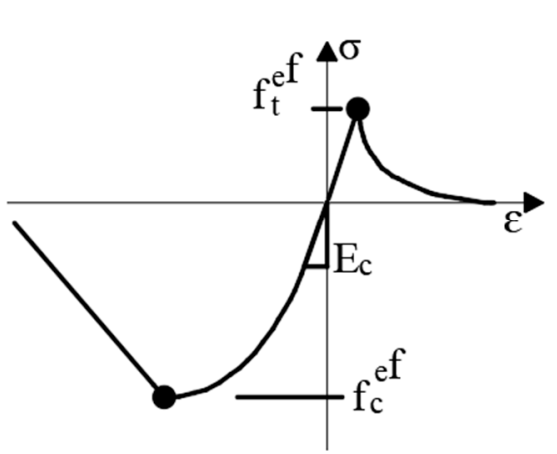

(a)

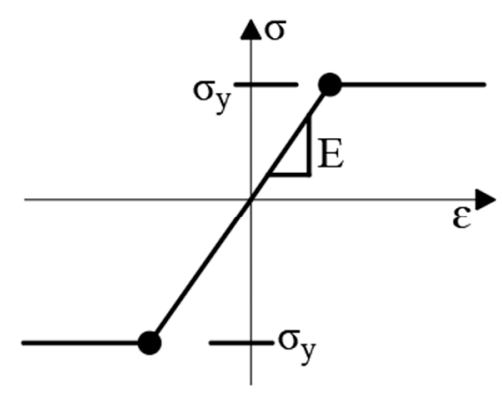

(b)

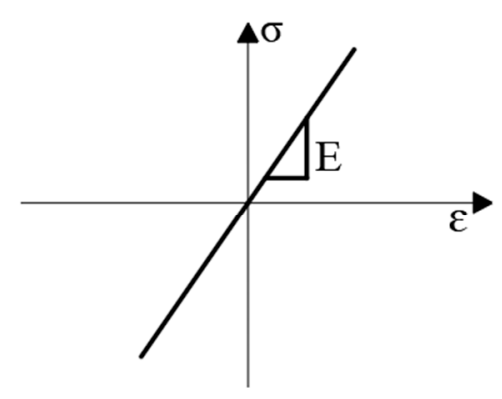

(c)

Figure 7. Material stress-strain models used in finite element analysis (a) concrete, (b) steel reinforcement, and (c) CFRP plate.

\section{Results and Discussion}

\subsection{Experimental Results}

The results of the experimental study [1] are presented in the form of load-deflection curves and crack patterns. The first crack in the control beam occurred at an average load of $3.3 \mathrm{kN}$, while for the beam with CFRP plates, the first crack occurred at an average load of $9.4 \mathrm{kN}$. Based on the test result, all control beams (G6C1, G6C2, and G6C3) and beam strengthened with the CFRP plate (G6P3) failed in flexure as indicated by concrete crushing in the top of the compression zone after the yielding of the tensile reinforcement. Two of the beams that were strengthened with CFRP plates (G6P1 and G6P2) failed prematurely due to the debonding of the CFRP plates indicated by concrete cover separation starting at a plate end and then propagating along the CFRP plate interface toward the middle of the beam.

Figure 8 shows the crack pattern of the test beam. The growth of flexural cracks on the stress side of the beam is followed by shear cracks that spread in the shear span zone. In beams with CFRP plate reinforcement, the cracking loads were higher than those in the control beams, due to the contribution of CFRP plates.

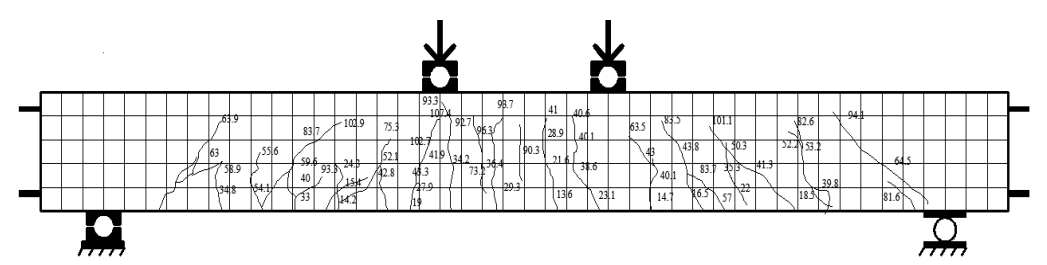

(a)

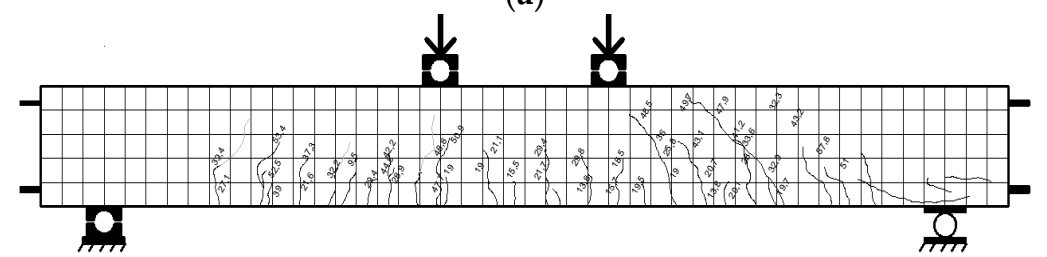

(b)

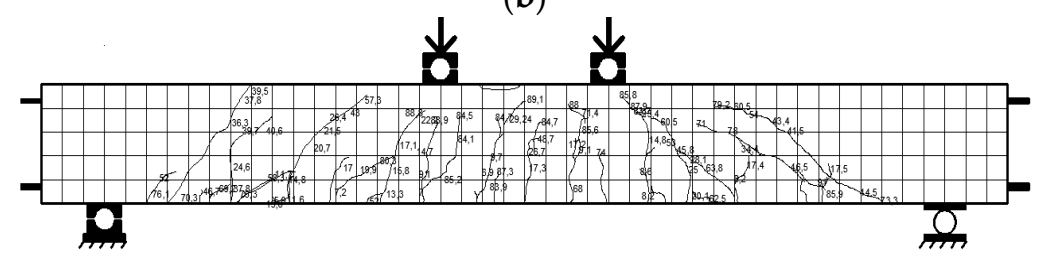

(c)

Figure 8. Cont. 


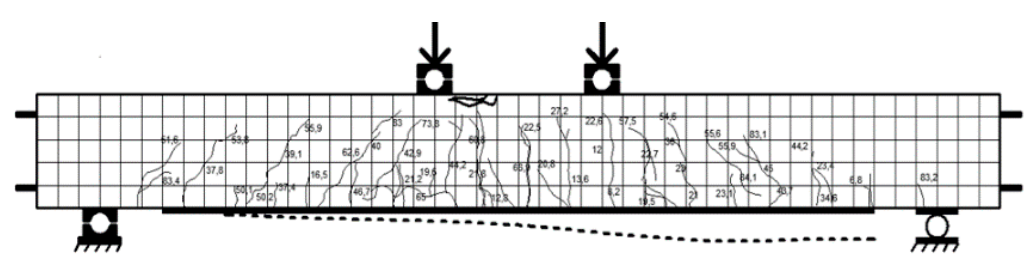

(d)

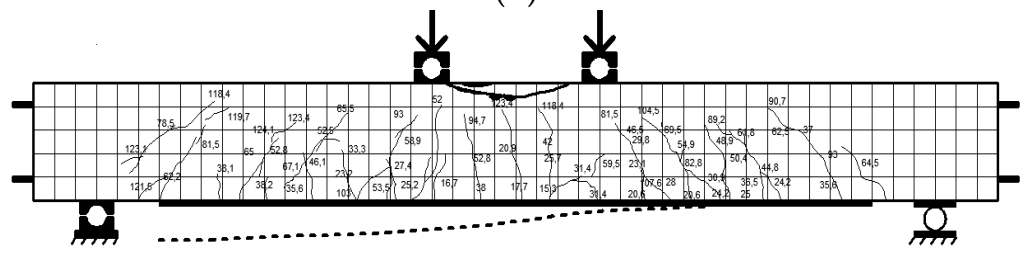

(e)

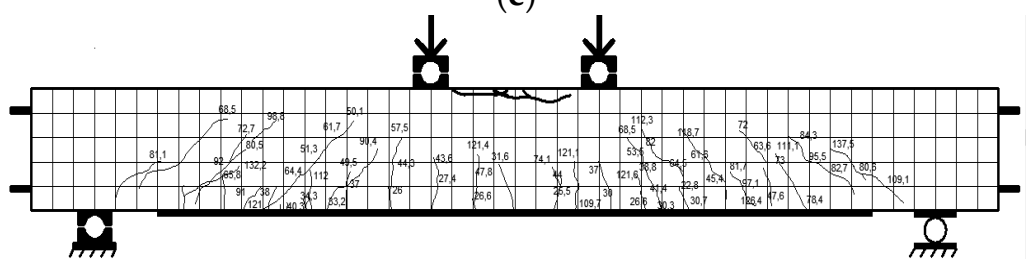

(f)

Figure 8. Crack patterns of the beams after the test (a) G6C1, (b) G6C2, (c) G6C3, (d) G6P1, (e) G6P2, and (f) G6P3.

The angle of the shear crack was higher in beams with smaller tensile reinforcement ratios, as shown in Figure 8. In reinforced concrete beams with a lower tensile reinforcement ratio, bending behavior was more dominant, while in beams with a higher tensile reinforcement ratio, the shear force increased as flexural capacity increased.

As shown in Figure 8, all beams showed a crushing of concrete in the compression zone. This is because, in experimental studies, if debonding failure occurred (for G6P1 and G6P2 beams), the load was continuously applied until the beam reached concrete crushing in the top of the compression zone. The debonding failure between the concrete and the CFRP plate occurred suddenly without any indication of delamination. The failure load occurred at the load levels of 48.9 and $63.1 \mathrm{kN}$ for beams G6P1 and G6P2, respectively. The location of delamination between the concrete and the CFRP plate on the G6P1 and G6P2 beams is shown in Figure 9.

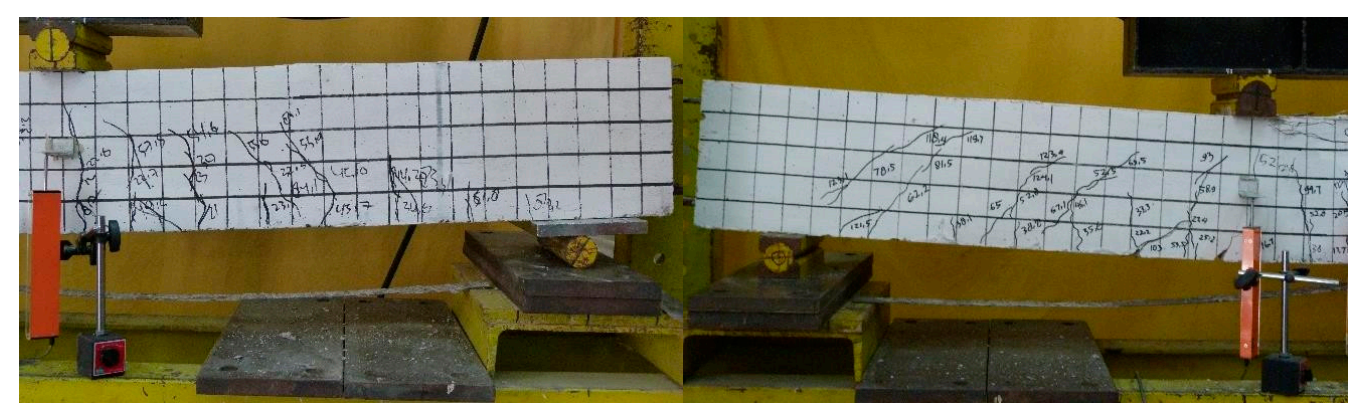

(a)

(b)

Figure 9. Debonding zone of beams with CFRP plates (a) G6P1, and (b) G6P2.

Figure 10 shows the flexural capacity of the test beam. It can be seen that an increase in the tensile strength ratio causes an increase in flexural capacity but also causes a decrease in beam ductility. A sudden drop in the load-deflection curve occurs due to delamination of the CFRP plate, as shown in Figure 10b. After delaminating the CFRP plate, the load immediately drops to the same load position as the control beam, as shown in Figure 10a. 
This phenomenon indicates that on the plated beams, the delamination of CFRP on the strengthened beam causes the beam to return to its unplated capacity after the influence of the CFRP plate was removed.

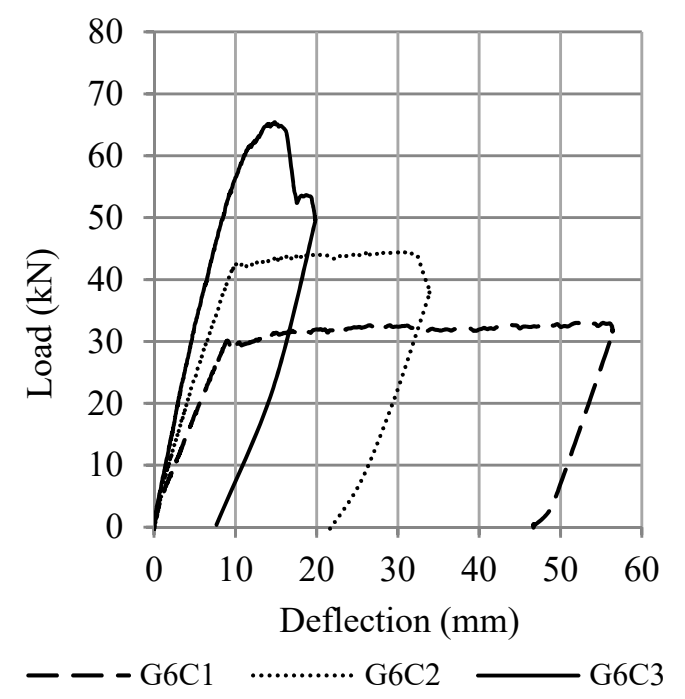

(a)

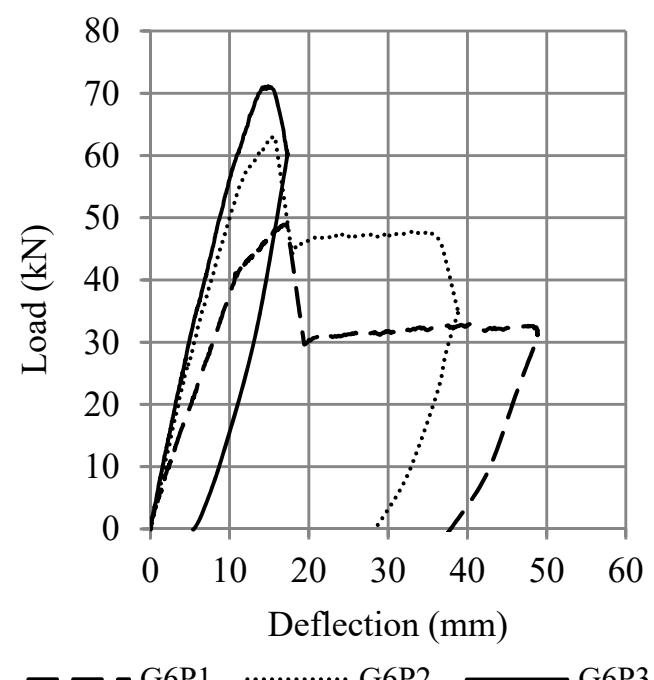

(b)

Figure 10. Load-deflection curve from the tested beams (a) control beams, and (b) beams with CFRP plates.

The flexural capacity of reinforced concrete beams with CFRP plates was $10 \%$ to $50 \%$ higher than the control beams, depending on the value of the reinforcement ratio, as shown in Figures 11 and 12. Figure 11 compares the results of fiber element method (G6P1-A1, G6P2-A1, G6P3-A1) with experimental results (G6P1, G6P2, G6P3) and Figure 12 compares the results of finite element method (G6P1-A2, G6P2-A2, G6P3-A2) with experimental results. The comparison shows that the fiber element method can predict the flexural response of the test beam with reasonable accuracy. The analysis confirmed that the flexural capacity of beams with CFRP plates is 8 to $55 \%$ higher than beams without plates depending on the value of the longitudinal reinforcement ratio. These figures also confirm that debonding failure occurred after yielding of the tensile reinforcement (G6P1 and G6P2).

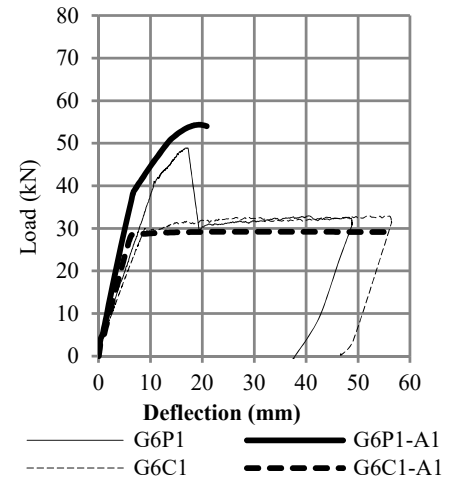

(a)

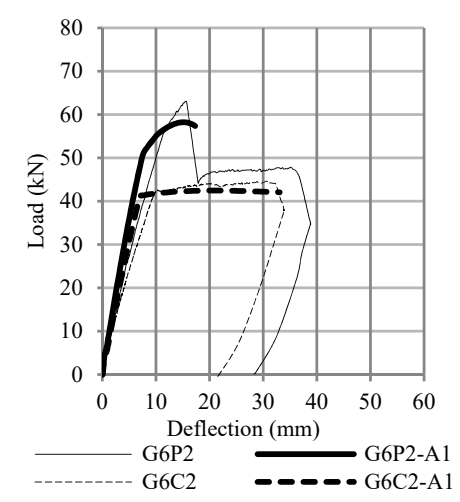

(b)

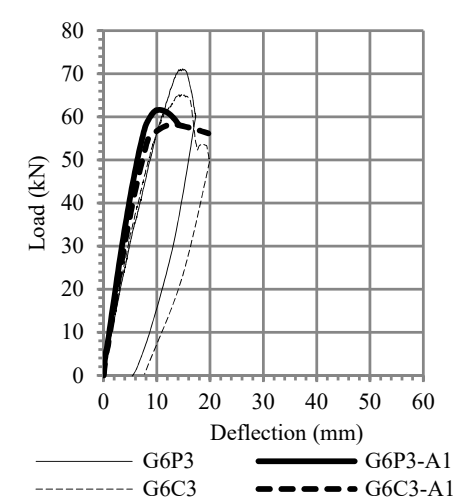

(c)

Figure 11. Comparison between test results and the fiber element method (RCCSA) (a) reinforcement ratio 1\%, (b) reinforcement ratio $1.5 \%$, and (c) reinforcement ratio $2.5 \%$. 


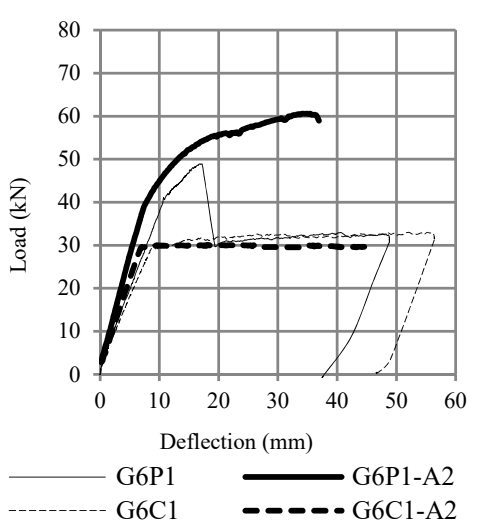

(a)

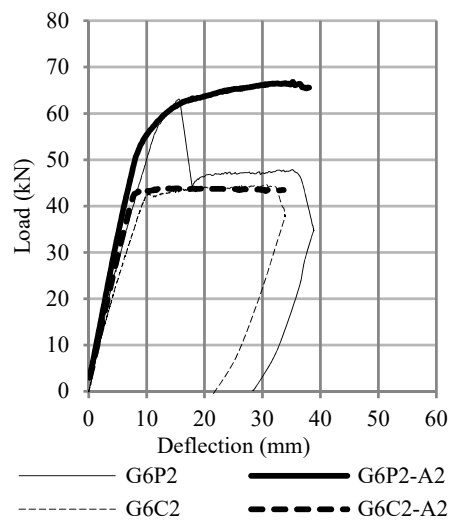

(b)

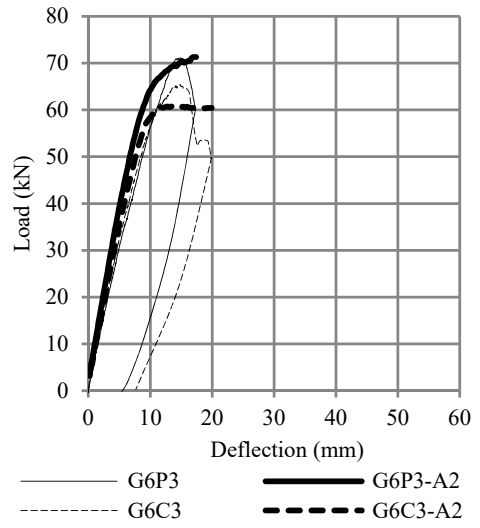

(c)

Figure 12. Comparison between test results and the finite element method (ATENA 2D) (a) reinforcement ratio $1 \%$, (b) reinforcement ratio $1.5 \%$, and (c) reinforcement ratio $2.5 \%$.

\subsection{Parametric Study}

Moreover, the fiber element method was applied to estimate the effect of tensile reinforcement ratio, modulus elasticity of the concrete, and plate thickness on the flexural capacity of RC beam strengthened with CFRP plate. The results of this analysis are shown in Figure 13. It is shown that all three variables increase flexural capacity.

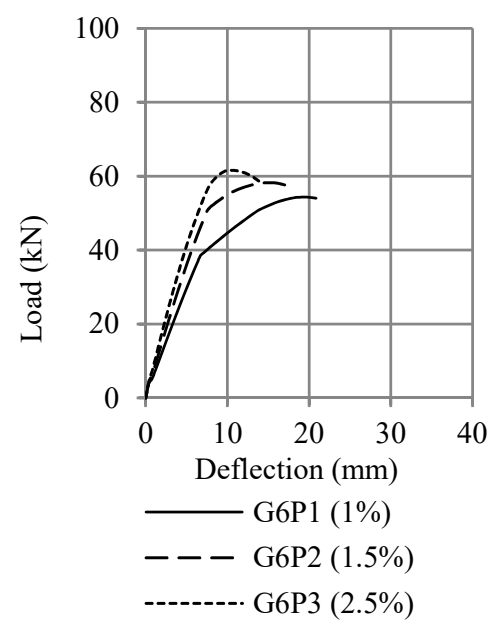

(a)

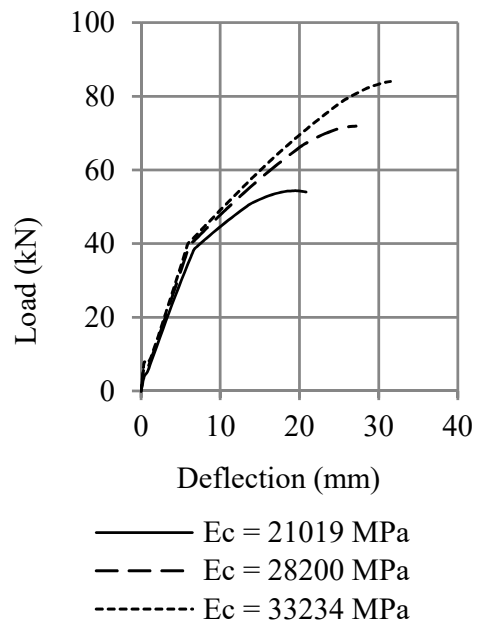

(b)

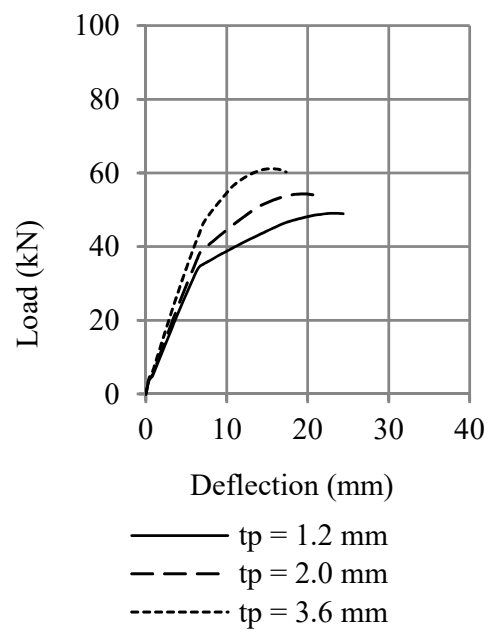

(c)

Figure 13. Effect of (a) ratio of tensile reinforcement, (b) the elastic modulus of the concrete, and (c) plate thickness on the flexural capacity using RCCSA.

To examine the effect of the ratio of tensile reinforcement, the elastic modulus of the concrete, and plate thickness on the strain of the concrete in the shear span zone using twodimensional finite element analysis, ATENA 2D software was used in this study. Figure 14 shows the three monitoring points applied on the finite element model; the first one is to monitor the load, the second is to monitor the deflection at the middle of the beam, and the third one is to monitor the strain on the concrete parallel to the tensile reinforcement and above the end of the CFRP plate.

The results of the analysis are shown in Figure 15. As the ratio of tensile reinforcement, modulus elasticity of the concrete, and plate thickness increase, the strain at the monitoring positions also increased. 


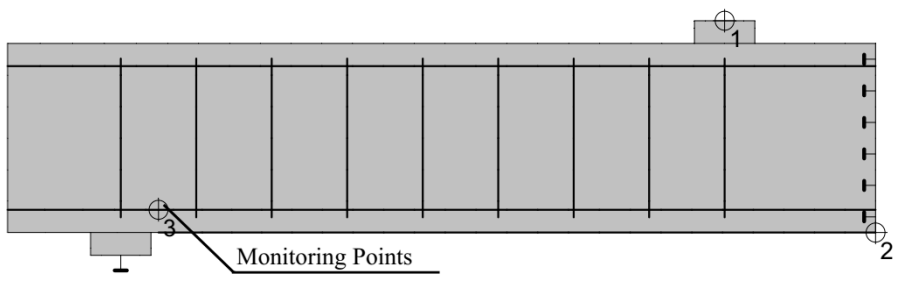

Figure 14. Position of monitoring points in the finite element model.

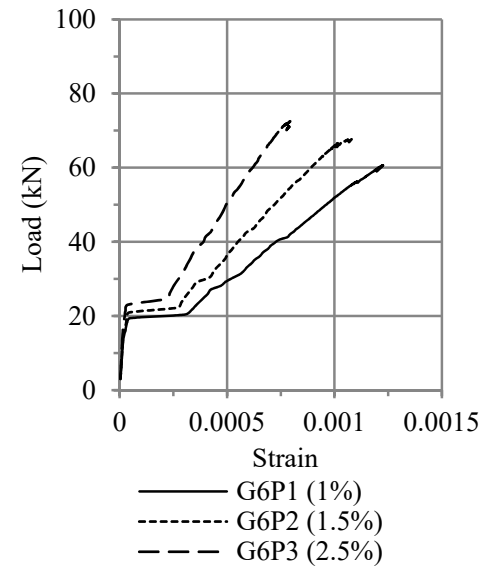

(a)

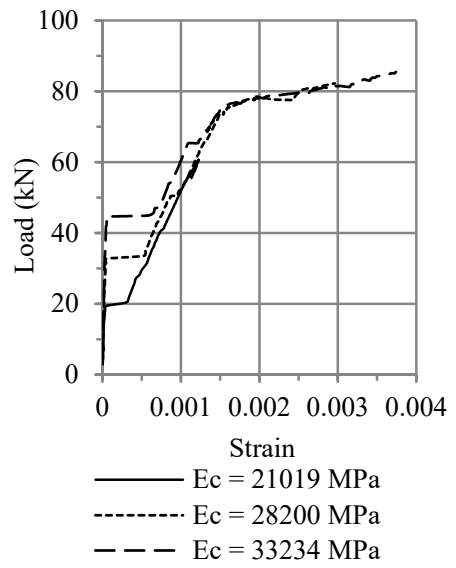

(b)

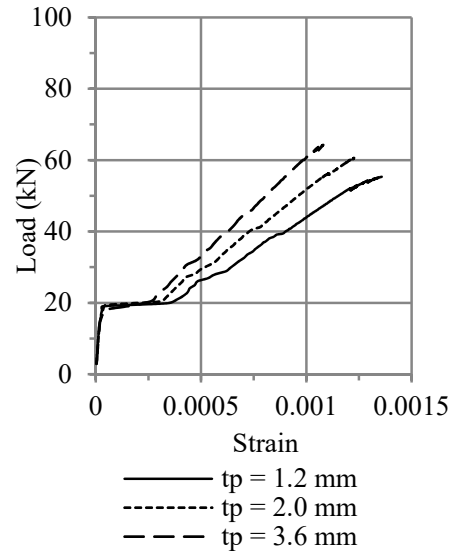

(c)

Figure 15. Effect of (a) ratio of tensile reinforcement, (b) the elastic modulus of the concrete, and (c) plate thickness on the strain of tensile reinforcement using ATENA.

Based on the results of the parametric study above, it was found that the three variables evaluated were the main variables in the debonding failure analysis. These three variables were then used in the model for predicting the debonding moment.

\subsection{Debonding Failure Analysis}

Many empirical equations for flexural debonding moments have been suggested in the literature. Two of them, listed in Table 1, were used in this study. It can be seen in Table 1 that both the equations listed take into account the thickness of the FRP plate, the modulus of elasticity of concrete, and the modulus of elasticity of the plate. The equations use different constant values because of mathematical functions used to model the observed data and the statistical approach used to analyze the data.

Table 1. Empirical equations for debonding moment from the literature.

\begin{tabular}{lcc}
\hline Literature & \multicolumn{2}{c}{ Empirical Equations for Debonding Moment } \\
\hline Oehlers [21] & $M_{d b, f}=\frac{E_{c} I_{t r, c} f_{c t}}{0.901 E_{f r p} t_{f r p}}$ & Equation (6) \\
\hline Teng \& Chen [22] & $M_{d b, f}=\frac{0.488 M_{u, 0}}{\left(\alpha_{f l e x} \alpha_{a x i a l} \alpha_{w w}\right)}$ & Equation (7) \\
\hline where: $\alpha_{f l e x}=\frac{\left[(E I)_{c, f r p}-(E I)_{c, 0}\right]}{(E I)_{c, 0}}, \alpha_{a x i a l}=\frac{E_{f r p} t_{f r p}}{E_{c} d}, \alpha_{w}=\frac{b_{c}}{b_{f r p}}, M_{d b, f}$ means flexural debonding moment, $E_{c}$ and $E_{f r p}$ \\
are the elastic modulus of the concrete and the elastic modulus of the FRP, respectively, $I_{t r, c}$ is the cracked second \\
moment of the area of the plated section transformed to concrete, $f_{c t}$ is the cylinder splitting tensile strength \\
of concrete, $b_{f r p}$ and $t_{f r p}$ are the width and thickness of the FRP plate, respectively, and $M_{u, 0}$ is the theoretical \\
ultimate moment of the unplated section, which is also the upper bound of the flexural debonding moment $M_{d b, f}$. \\
$\alpha_{f l e x}, \alpha_{a x i a l}$ and $\alpha_{w}$ are three dimensionless variables, $(E I)_{c, f r p}$ and $(E I)_{c, 0}$ are the flexural rigidities of the cracked \\
section with and without an FRP plate, respectively, and $b_{c}$ and $d$ are the widths and effective depth of the RC \\
beam, respectively.
\end{tabular}


In this study, the author modeled the debonding moment using basic equations from bending theory. The equation for calculating the crack moment $\left(M_{c r}\right)$ in a square cross-section of concrete, as shown in Equation (8), was used.

$$
M_{c r}=\frac{f_{t} I}{y}
$$

where $f_{t}$ is the tensile strength of concrete, $I$ is the moment of inertia, and $y$ is the distance from the centroidal axis of the beam cross-section.

Assuming $y=h / 2$ and a moment of inertia $I=(1 / 12) b h^{3}$, we modified Equation (9) as;

$$
M_{d b}=\frac{1}{6} f_{t} b_{w} h^{2}
$$

The experimental test results of the study by Thamrin et al. [1] and Ross et al. [4] are plotted in Figure 16a to examine the effect of the tensile reinforcement ratio on the debonding load. Data from the experimental study by Khomwan et al. [11] and Fu et al. [17] were plotted in Figure 16b to obtain the effect of the ratio of the modulus of elasticity of concrete $\left(E_{c}\right)$ with that of the plate $\left(E_{p}\right)$ on the debonding load. Furthermore, Figure $16 c$ plots the effect of the CFRP plate thickness on the debonding load using the data from the study by Kotynia et al. [13] and Ahmed et al. [15]. These plot results show that the longitudinal tensile reinforcement ratio, $E_{c} / E_{p}$, and plate thickness ratio significantly affect the debonding load.

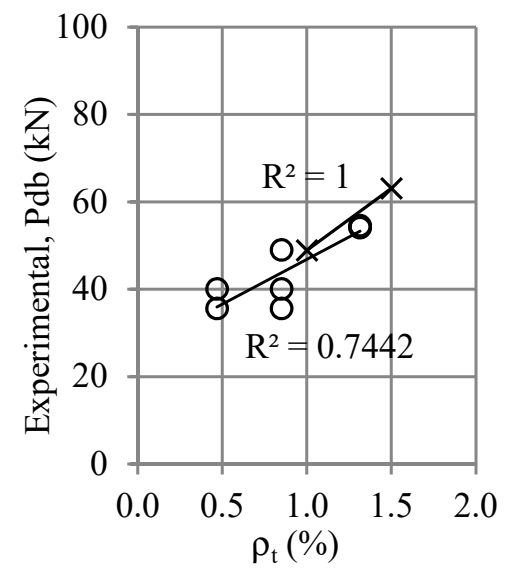

$\times$ Thamrin, et al [1]

o Ross, et al [4]

(a)

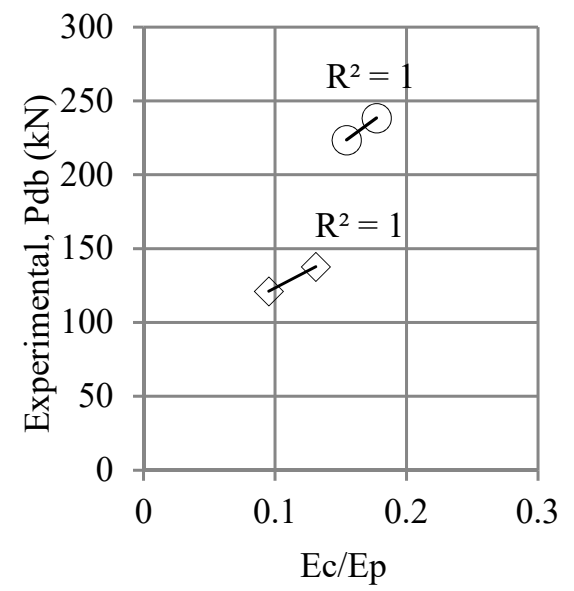

O Khomwan, et al [11] $\diamond \mathrm{Fu}$, et al [17]

(b)

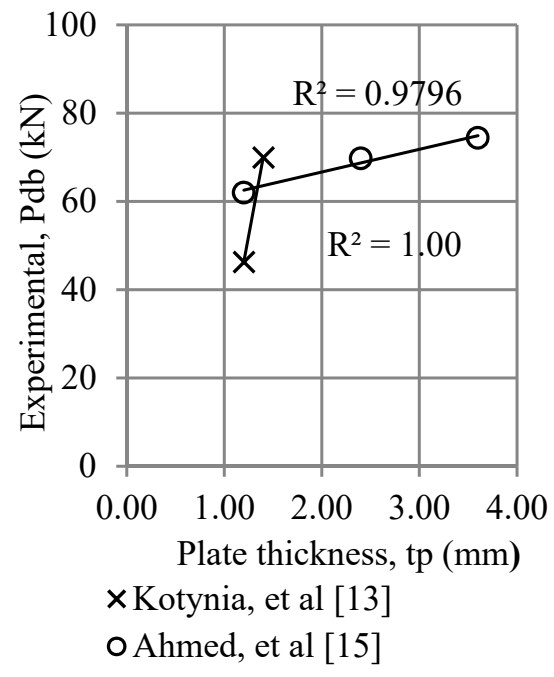

(c)

Figure 16. Effect of (a) ratio of tensile reinforcement, (b) $E_{c} / E_{p}$, and (c) the plate thickness on the debonding loads.

Therefore, the three variables that affect the debonding moment applied in the model proposed in this study are: (1) the effect of the longitudinal tensile reinforcement ratio is expressed as $\alpha,(2)$ the ratio of $E_{c} / E_{p}$ is expressed as $\beta$ and (3) the effect of plate thickness as $t_{p}$. The effect of these three variables is shown in Equation (10).

$$
M_{d b}=\frac{1}{6} \alpha \beta t_{p} b_{w} h^{2} f_{t}
$$

Simple statistical analysis was performed to determine the value of the constants $\omega$ and to fit the test data for the debonding moment equation, as expressed in Equation (11).

$$
M_{d b}=\omega \alpha \beta t_{p} b_{w} h^{2} f_{t}
$$


where: $\omega$ is a constant for the debonding moment equation and is expressed in a unit of $1 / \mathrm{mm}, \alpha=100 \rho_{t}, \rho_{t}$ is the ratio of tensile reinforcement, $\beta=E_{c} / E_{p}, E_{c}$ is the modulus of elasticity of concrete, $E_{p}$ is the modulus of elasticity of the plate, $t_{p}$ is the plate thickness, $b_{w}$ is the width of the RC beam, $h$ is the height of the rectangular concrete member, and $f_{t}$ is the splitting tensile strength; if the splitting tensile strength is not determined from tests, then the value of the concrete tensile strength can be calculated as $f_{t}=f_{c}{ }^{\prime} / 10$.

To assess the accuracy of the proposed model, we used the test results from this study, selected additional data from the literature [1-17], and we summarized the data in a database of 60 existing RC beam tests. The selected beams were simply supported, rectangular or square in cross-section, and retrofitted with CFRP plates on their soffits. The beams in the database list failed either due to flexural failure or debonding. The database includes a wide variety of beam configurations. The beam spans vary from 0.94 to $6.5 \mathrm{~m}$. The beam section aspect ratios, width over depth, range from 0.36 to 3.00. The concrete strengths reported ranged from 17.4 to $80 \mathrm{MPa}$. The CFRP plate thickness varied from 0.45 to $3.6 \mathrm{~mm}$. The variation of the tensile reinforcement ratio ranged from $0.39 \%$ to $10.17 \%$. The assessment of the proposed debonding load formula (with $\omega=6$ ) was carried out on data points of adopted data from RC beams strengthened with CFRP plates. The results can be seen in Table 2 .

Table 2. Test results and theoretical values of the debonding load.

\begin{tabular}{|c|c|c|c|c|c|c|c|c|c|c|c|c|c|}
\hline \multirow{2}{*}{ Specimen } & $f c^{\prime}$ & $f t$ & $E_{c}$ & $b_{w}$ & $h$ & $a$ & $\rho_{t}$ & $t_{p}$ & $E_{p}$ & $\begin{array}{l}\text { Oehlers } \\
\text { [21] }\end{array}$ & $\begin{array}{c}\text { Teng\&Chen } \\
\text { [22] }\end{array}$ & $\begin{array}{c}\text { Proposed } \\
\text { Model }\end{array}$ & $P_{\text {exp }}$ \\
\hline & (MPa) & (MPa) & (GPa) & $(\mathrm{mm})$ & $(\mathrm{mm})$ & $(\mathrm{mm})$ & & $(\mathrm{mm})$ & (GPa) & $(\mathrm{kN})$ & $(\mathbf{k N})$ & $(\mathbf{k N})$ & $(\mathrm{kN})$ \\
\hline \multicolumn{14}{|c|}{ Thamrin et al. [1] } \\
\hline G6P1 & 20 & 2.0 & 21 & 125 & 250 & 800 & 0.009 & 1.90 & 139 & 22.77 & 21.27 & 32.71 & 48.90 \\
\hline G6P2 & 20 & 2.0 & 21 & 125 & 250 & 800 & 0.014 & 1.90 & 139 & 28.35 & 31.19 & 49.06 & 63.10 \\
\hline G6P3 & 20 & 2.0 & 21 & 125 & 250 & 800 & 0.023 & 1.90 & 139 & 37.35 & 47.15 & 81.77 & 71.15 \\
\hline \multicolumn{14}{|c|}{ Garden \& Hollaway [2] } \\
\hline Beam $1 \mathrm{U}, 1.0 \mathrm{~m}$ & 44.8 & 4.5 & 31 & 100 & 100 & 300 & 0.01 & 0.82 & 110 & 15.35 & 5.96 & 21.22 & 36.50 \\
\hline Beam 2 U,1.0 m & 44.8 & 4.5 & 31 & 100 & 100 & 300 & 0.01 & 0.82 & 110 & 15.35 & 5.96 & 21.22 & 32.00 \\
\hline Beam 3 U,1.0 m & 44.8 & 4.5 & 31 & 100 & 100 & 220 & 0.01 & 0.82 & 110 & 20.93 & 8.12 & 28.94 & 34.00 \\
\hline Beam 4 U,1.0 m & 44.8 & 4.5 & 31 & 100 & 100 & 100 & 0.01 & 0.82 & 110 & 46.04 & 17.87 & 63.66 & 34.50 \\
\hline Beam 5 U,1.0 m & 44.8 & 4.5 & 31 & 100 & 100 & 100 & 0.01 & 0.82 & 110 & 46.04 & 17.87 & 63.66 & 34.60 \\
\hline \multicolumn{14}{|c|}{ Spadea et al. [3] } \\
\hline A3.1 & 24.9 & 2.5 & 23 & 140 & 300 & 1800 & 0.011 & 1.20 & 152 & 32.22 & 18.47 & 21.14 & 37.40 \\
\hline \multicolumn{14}{|c|}{ Ross et al. [4] } \\
\hline $1 \mathrm{~B}$ & 54.8 & 5.5 & 35 & 200 & 200 & 914 & 0.0047 & 0.45 & 138 & 60.01 & 7.92 & 15.19 & 40.05 \\
\hline $1 C$ & 54.8 & 5.5 & 35 & 200 & 200 & 914 & 0.0047 & 0.45 & 138 & 60.01 & 7.92 & 15.19 & 35.60 \\
\hline $2 \mathrm{~B}$ & 54.8 & 5.5 & 35 & 200 & 200 & 914 & 0.0085 & 0.45 & 138 & 80.06 & 15.10 & 27.57 & 48.95 \\
\hline $2 \mathrm{C}$ & 54.8 & 5.5 & 35 & 200 & 200 & 914 & 0.0085 & 0.45 & 138 & 80.06 & 15.10 & 27.57 & 35.60 \\
\hline $2 \mathrm{D}$ & 54.8 & 5.5 & 35 & 200 & 200 & 914 & 0.0085 & 0.45 & 138 & 80.06 & 15.10 & 27.57 & 40.05 \\
\hline $3 B$ & 54.8 & 5.5 & 35 & 200 & 200 & 914 & 0.0132 & 0.45 & 138 & 101.33 & 23.96 & 42.58 & 54.52 \\
\hline $3 C$ & 54.8 & 5.5 & 35 & 200 & 200 & 914 & 0.0132 & 0.45 & 138 & 101.33 & 23.96 & 42.58 & 54.07 \\
\hline $3 \mathrm{D}$ & 54.8 & 5.5 & 35 & 200 & 200 & 914 & 0.0132 & 0.45 & 138 & 101.33 & 23.96 & 42.58 & 54.29 \\
\hline $4 \mathrm{~B}$ & 54.8 & 5.5 & 35 & 200 & 200 & 914 & 0.0187 & 0.45 & 138 & 123.76 & 34.60 & 60.68 & 53.82 \\
\hline $4 C$ & 54.8 & 5.5 & 35 & 200 & 200 & 914 & 0.0187 & 0.45 & 138 & 123.76 & 34.60 & 60.68 & 52.29 \\
\hline $4 \mathrm{D}$ & 54.8 & 5.5 & 35 & 200 & 200 & 914 & 0.0187 & 0.45 & 138 & 123.76 & 34.60 & 60.68 & 55.63 \\
\hline $5 \mathrm{~B}$ & 54.8 & 5.5 & 35 & 200 & 200 & 914 & 0.0201 & 0.45 & 138 & 128.85 & 37.19 & 65.15 & 73.43 \\
\hline $5 C$ & 54.8 & 5.5 & 35 & 200 & 200 & 914 & 0.0201 & 0.45 & 138 & 128.85 & 37.19 & 65.15 & 73.43 \\
\hline $5 \mathrm{D}$ & 54.8 & 5.5 & 35 & 200 & 200 & 914 & 0.0201 & 0.45 & 138 & 128.85 & 37.19 & 65.15 & 72.76 \\
\hline $6 \mathrm{~B}$ & 54.8 & 5.5 & 35 & 200 & 200 & 914 & 0.0335 & 0.45 & 138 & 171.54 & 61.32 & 108.47 & 84.55 \\
\hline $6 C$ & 54.8 & 5.5 & 35 & 200 & 200 & 914 & 0.0335 & 0.45 & 138 & 171.54 & 61.32 & 108.47 & 76.55 \\
\hline \multicolumn{14}{|c|}{ Shehata et al. [5] } \\
\hline V1 & 33.3 & 3.3 & 27 & 150 & 450 & 1350 & 0.010 & 1.20 & 165 & 180.83 & 95.39 & 84.87 & 140.00 \\
\hline V3 & 34.3 & 3.4 & 28 & 150 & 450 & 1350 & 0.010 & 1.20 & 165 & 195.75 & 96.01 & 88.73 & 150.00 \\
\hline
\end{tabular}


Table 2. Cont

\begin{tabular}{|c|c|c|c|c|c|c|c|c|c|c|c|c|c|}
\hline \multirow{2}{*}{ Specimen } & $f c^{\prime}$ & $f t$ & $E_{c}$ & $b_{w}$ & $h$ & $a$ & $\rho_{t}$ & $t_{p}$ & $E_{p}$ & $\begin{array}{c}\text { Oehlers } \\
\text { [21] }\end{array}$ & $\begin{array}{l}\text { Teng\&Chen } \\
\text { [22] }\end{array}$ & $\begin{array}{c}\text { Proposed } \\
\text { Model }\end{array}$ & $P_{\exp }$ \\
\hline & (MPa) & (MPa) & (GPa) & $(\mathrm{mm})$ & $(\mathrm{mm})$ & $(\mathrm{mm})$ & & $(\mathrm{mm})$ & (GPa) & $(\mathrm{kN})$ & $(\mathrm{kN})$ & $(\mathrm{kN})$ & $(\mathrm{kN})$ \\
\hline \multicolumn{14}{|c|}{ Nguyen et al. [6] } \\
\hline A950 & 26.6 & 2.7 & 24 & 120 & 150 & 440 & 0.016 & 1.20 & 181 & 15.61 & 14.34 & 25.80 & 28.10 \\
\hline A1100 & 26.6 & 2.7 & 24 & 120 & 150 & 440 & 0.016 & 1.20 & 181 & 15.61 & 14.34 & 25.80 & 28.65 \\
\hline A1150 & 26.6 & 2.7 & 24 & 120 & 150 & 440 & 0.016 & 1.20 & 181 & 15.61 & 14.34 & 25.80 & 29.45 \\
\hline B1 & 37.0 & 3.7 & 29 & 120 & 150 & 440 & 0.004 & 1.20 & 181 & 12.73 & 3.53 & 10.14 & 24.60 \\
\hline B2 & 37.0 & 3.7 & 29 & 120 & 150 & 440 & 0.044 & 1.20 & 181 & 28.95 & 41.41 & 112.69 & 65.05 \\
\hline $\mathrm{C} 5$ & 20.8 & 2.1 & 21 & 120 & 150 & 440 & 0.014 & 1.20 & 181 & 16.67 & 17.41 & 15.29 & 35.50 \\
\hline $\mathrm{C} 10$ & 20.8 & 2.1 & 21 & 120 & 150 & 440 & 0.015 & 1.20 & 181 & 15.74 & 16.41 & 15.86 & 34.00 \\
\hline $\mathrm{C} 20$ & 20.8 & 2.1 & 21 & 120 & 150 & 440 & 0.016 & 1.20 & 181 & 14.02 & 14.47 & 17.13 & 31.50 \\
\hline \multicolumn{14}{|c|}{ Fanning \& Kelly [7] } \\
\hline F5 & 80 & 5.0 & 39 & 155 & 240 & 1100 & 0.011 & 1.20 & 155 & 69.59 & 25.51 & 79.64 & 50.00 \\
\hline F6 & 80 & 5.0 & 39 & 155 & 240 & 1100 & 0.011 & 1.20 & 155 & 69.59 & 25.51 & 79.64 & 51.50 \\
\hline F7 & 80 & 5.0 & 39 & 155 & 240 & 1100 & 0.011 & 1.20 & 155 & 69.59 & 25.51 & 79.64 & 48.75 \\
\hline F8 & 80 & 5.0 & 39 & 155 & 240 & 1100 & 0.011 & 1.20 & 155 & 69.59 & 25.51 & 79.64 & 32.00 \\
\hline F9 & 80 & 5.0 & 39 & 155 & 240 & 1100 & 0.011 & 1.20 & 155 & 69.59 & 25.51 & 79.64 & 31.00 \\
\hline F10 & 80 & 5.0 & 39 & 155 & 240 & 1100 & 0.011 & 1.20 & 155 & 69.59 & 25.51 & 79.64 & 41.00 \\
\hline \multicolumn{14}{|c|}{ Breña et al. [8] } \\
\hline D1 & 37.2 & 3.7 & 29 & 203 & 406 & 1220 & 0.005 & 1.19 & 155 & 128.10 & 41.78 & 72.10 & 64.05 \\
\hline D2 & 37.2 & 3.7 & 29 & 203 & 406 & 1220 & 0.005 & 1.19 & 155 & 128.10 & 41.78 & 72.10 & 66.95 \\
\hline \multicolumn{14}{|c|}{ Breña et al. [9] } \\
\hline A6-I & 47.7 & 4.8 & 33 & 100 & 100 & 330 & 0.008 & 1.19 & 155 & 7.98 & 5.14 & 17.44 & 34.80 \\
\hline \multicolumn{14}{|c|}{ Pimanmas et al. [10] } \\
\hline B-200P & 44 & 4.4 & 31 & 120 & 220 & 700 & 0.033 & 1.20 & 150 & 51.45 & 51.12 & 180.95 & 117.79 \\
\hline \multicolumn{14}{|c|}{ Khomwan et al. [11] } \\
\hline B2 & 37 & 3.7 & 25 & 350 & 700 & 2500 & 0.006 & 1.40 & 165 & 467.07 & 142.64 & 191.97 & 223.50 \\
\hline B6 & 53 & 5.3 & 29 & 350 & 700 & 2500 & 0.006 & 1.40 & 165 & 574.57 & 147.06 & 315.70 & 238.50 \\
\hline \multicolumn{14}{|c|}{ Benjeddou et al. [12] } \\
\hline RB1 & 21 & 1.86 & 30 & 120 & 150 & 600 & 0.010 & 1.20 & 165 & 9.20 & 7.91 & 11.47 & 20.06 \\
\hline \multicolumn{14}{|c|}{ Kotynia et al. [13] } \\
\hline B-08 S & 32.3 & 2.8 & 27 & 150 & 300 & 1400 & 0.008 & 1.20 & 172 & 38.35 & 23.28 & 25.28 & 46.30 \\
\hline B-08 M & 37.3 & 3.5 & 29 & 150 & 300 & 1400 & 0.008 & 1.40 & 220 & 43.51 & 21.83 & 30.97 & 70.00 \\
\hline \multicolumn{14}{|c|}{ Al-Tamimi et al. [14] } \\
\hline $\mathrm{B} 85 \mathrm{P}$ & 54 & 5.4 & 35 & 110 & 180 & 562 & 0.009 & 1.40 & 215 & 24.21 & 16.50 & 42.59 & 30.35 \\
\hline B25P & 54 & 5.4 & 35 & 110 & 180 & 562 & 0.009 & 1.40 & 215 & 24.21 & 16.50 & 42.59 & 25.97 \\
\hline B70P & 54 & 5.4 & 35 & 110 & 180 & 562 & 0.009 & 1.40 & 215 & 24.21 & 16.50 & 42.59 & 23.54 \\
\hline \multicolumn{14}{|c|}{ Ahmed et al. [15] } \\
\hline FB-1L & 36 & 3.0 & 29 & 150 & 200 & 700 & 0.006 & 1.20 & 165 & 24.85 & 11.81 & 19.66 & 31.00 \\
\hline FB-2L & 36 & 3.0 & 29 & 150 & 200 & 700 & 0.006 & 2.40 & 165 & 17.30 & 10.18 & 39.32 & 34.88 \\
\hline FB-3L & 36 & 3.0 & 29 & 150 & 200 & 700 & 0.006 & 3.60 & 165 & 14.52 & 9.35 & 58.98 & 37.20 \\
\hline \multicolumn{14}{|c|}{ Bilotta et al. [16] } \\
\hline EBR_c_1.4x40_1 & 17.43 & 1.74 & 20 & 120 & 160 & 925 & 0.013 & 1.40 & 171 & 3.23 & 4.17 & 7.02 & 18.25 \\
\hline EBR_c_1.4x40_2 & 17.43 & 1.74 & 20 & 120 & 160 & 925 & 0.013 & 1.40 & 171 & 4.42 & 4.20 & 7.02 & 17.60 \\
\hline \multicolumn{14}{|c|}{ Fu et al. [17] } \\
\hline B1S1 & 49 & 4.9 & 33 & 200 & 450 & 1300 & 0.008 & 0.67 & 251 & 286.39 & 83.90 & 61.75 & 137.70 \\
\hline B1S2 & 25.9 & 2.6 & 24 & 200 & 450 & 1300 & 0.005 & 0.67 & 251 & 149.99 & 50.20 & 15.82 & 121.20 \\
\hline
\end{tabular}

Comparison of literature models of the debonding load (Oehlers [21] and Teng and Chen [22]) with adopted 60 experimental test specimens are shown in Figure 17. It can be seen that both equations predict the debonding load conservatively, although some data are not conservative. Figure 18 compares the collected data results with the proposed 
model. The graph shows that the proposed model predicts the experimental results as well as the other models.

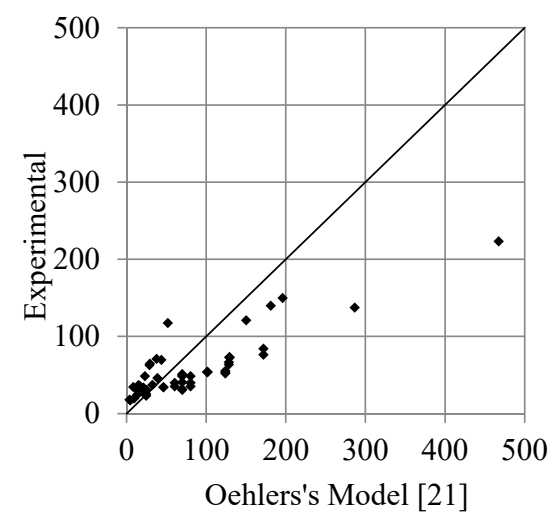

(a)

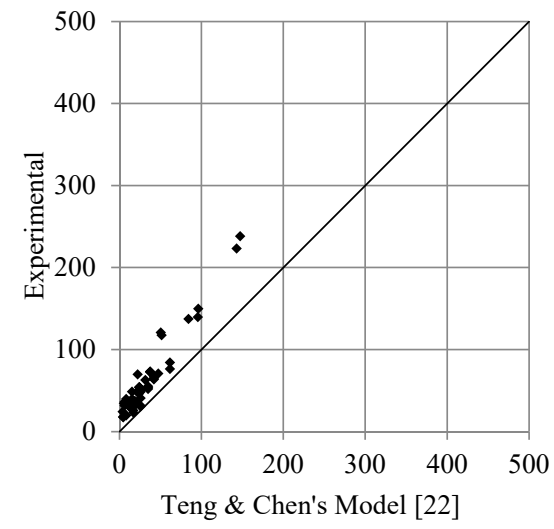

(b)

Figure 17. Comparison of the literature models of the debonding load (a) Oehler's Model [21], and (b) Teng \& Chen's Model [22], with experimental results.

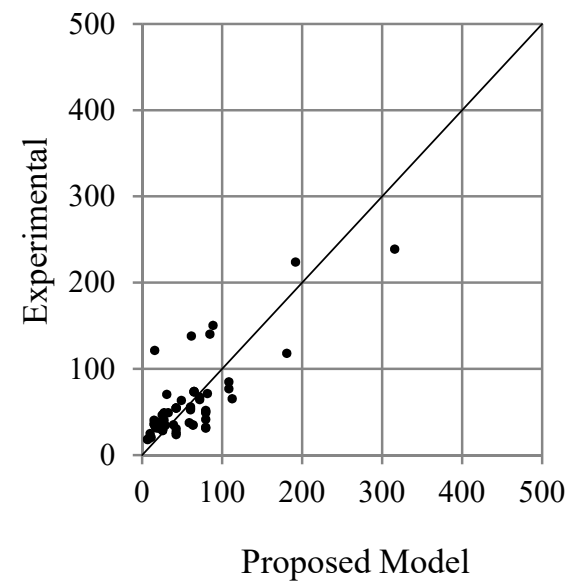

Figure 18. Comparison of the debonding load between the proposed model $(\omega=6)$ and the experimental results.

\subsection{Implementation of the Proposed Model on the RCCSA Software}

To check the validity of the proposed model, Equation (11) was implemented in the RCCSA software. The value of the debonding moment can be calculated after all of the variables in Equation (11) are entered into the data input block. For each step of incremental curvature, the obtained moment value is checked. The axial stiffness of the CFRP plate is removed when the moment value reaches the debonding moment value obtained from Equation (11).

Figures 19-22 compare the calculation results (using $\omega=6$ ) with some experimental data adopted from the literature [1-17]. The occurrence of debonding failure results in a sudden drop of load on the load-deflection curve, as shown in Figures 19-21. From these plots, based on the prediction results using Equation (11), there are four types of results. The four types are: (1) debonding failure occurs before the experimental debonding load and after yielding of the tensile reinforcement (see Figure 19), (2) debonding failure occurs before yielding of the tensile reinforcement (see Figure 20), (3) debonding failure value is higher than experimental debonding load (see Figure 21), and (4) the value of the calculated debonding moment is higher than the ultimate nominal moment of the cross-section (debonding failure does not occur, see Figure 22). 

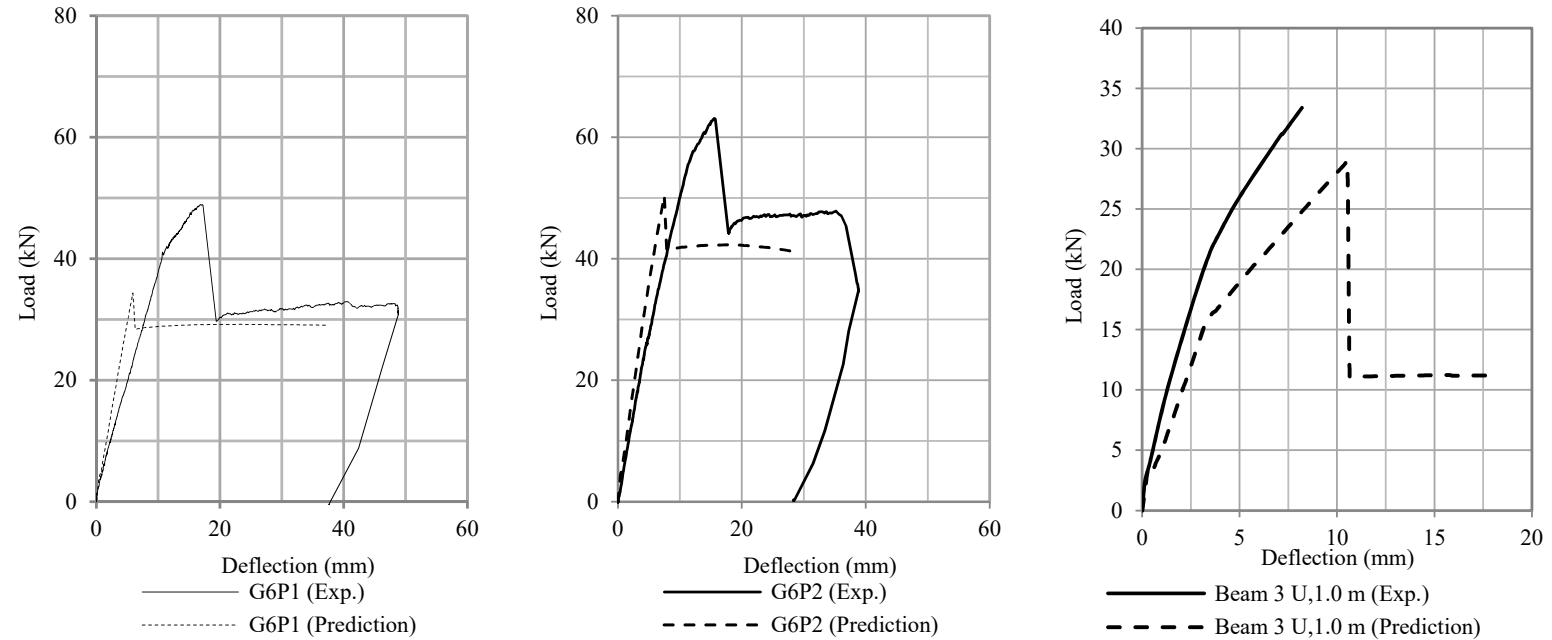

(a)

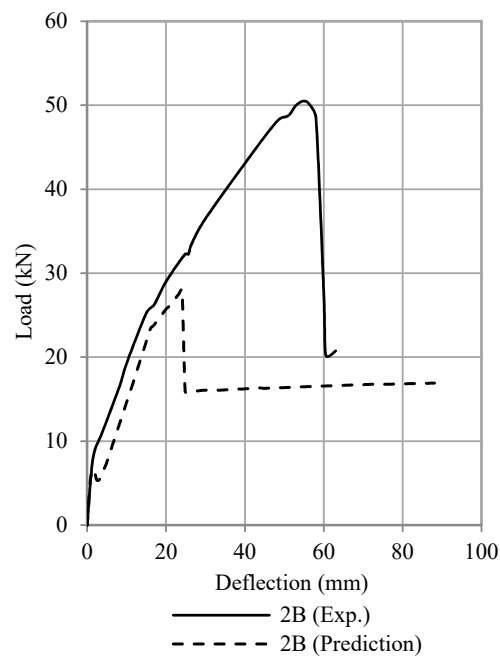

(c)

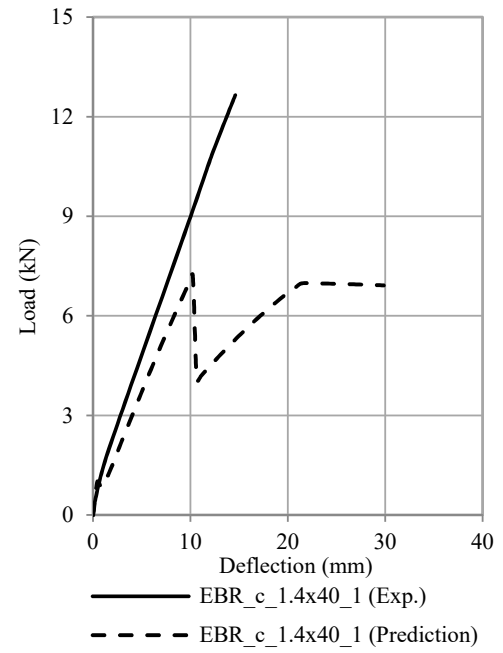

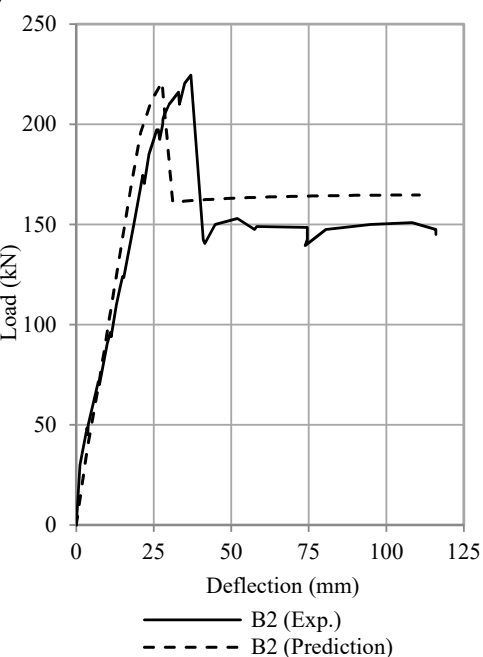

(d) (b)

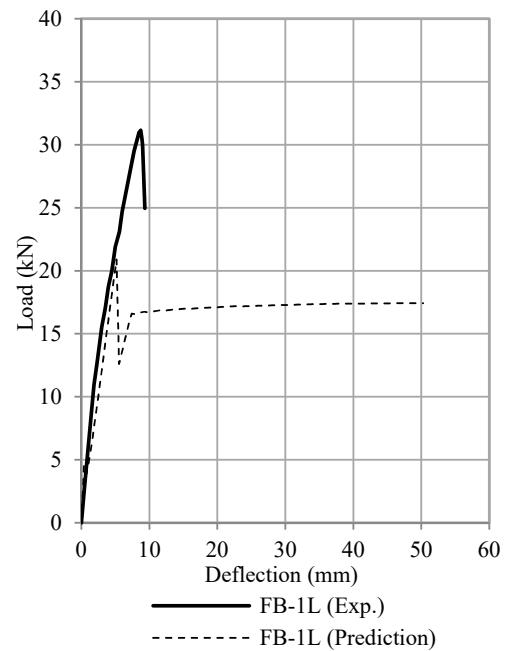

(e)

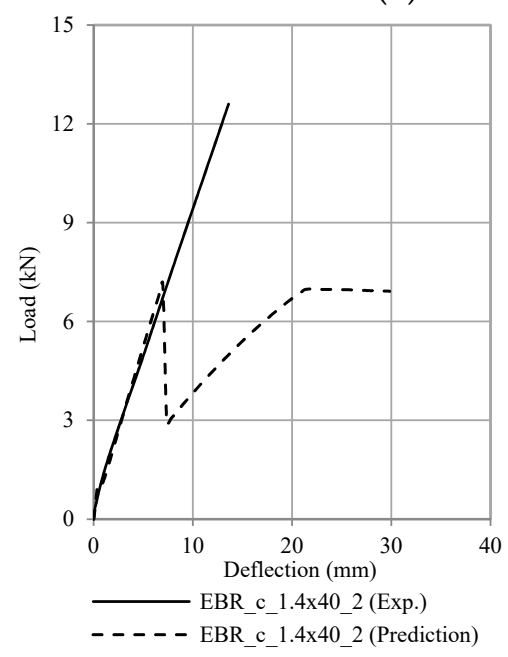

(f)

Figure 19. Comparison of the debonding load between the experimental results and the prediction (Type 1 debonding failure occurs before the experimental debonding load and after the yielding of tensile reinforcement) (a) Thamrin et al. [1], (b) Garden \& Hollaway [2], (c) Ross et al. [4], (d) Khomwan et al. [11], (e) Ahmed et al. [15], and (f) Bilotta et al. [16]. 


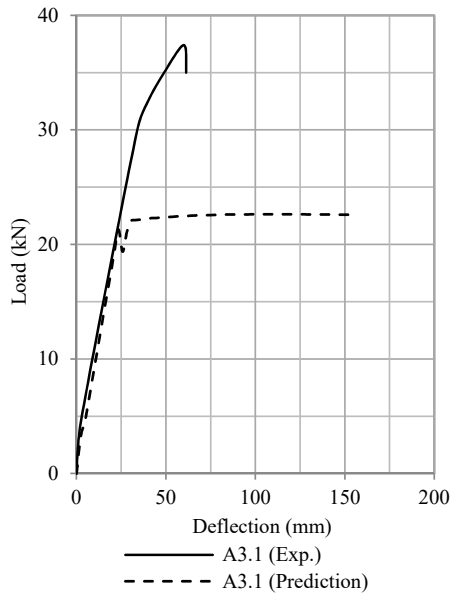

(a)

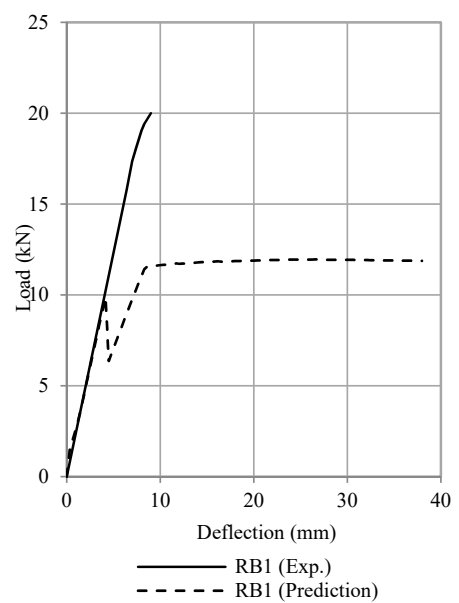

(c)

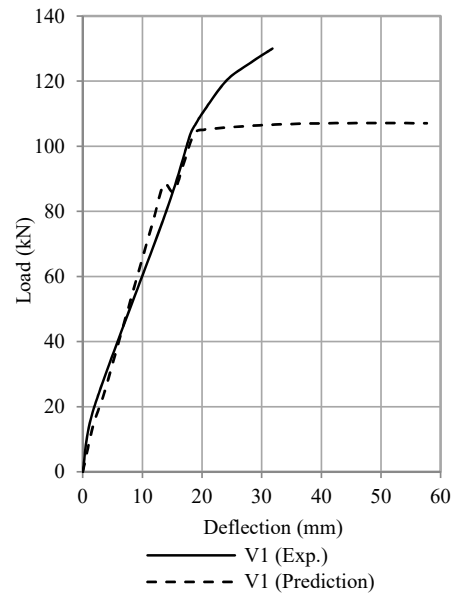

(b)

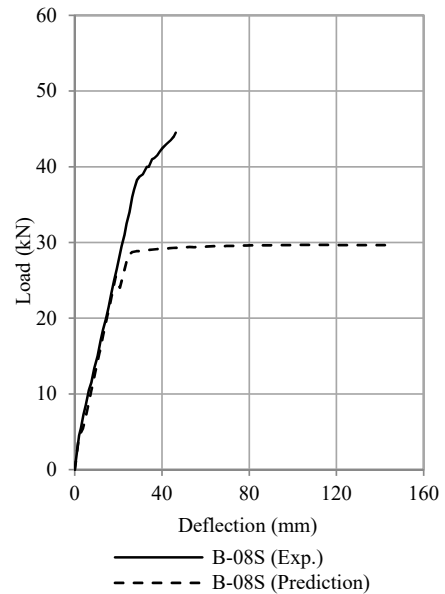

(d)
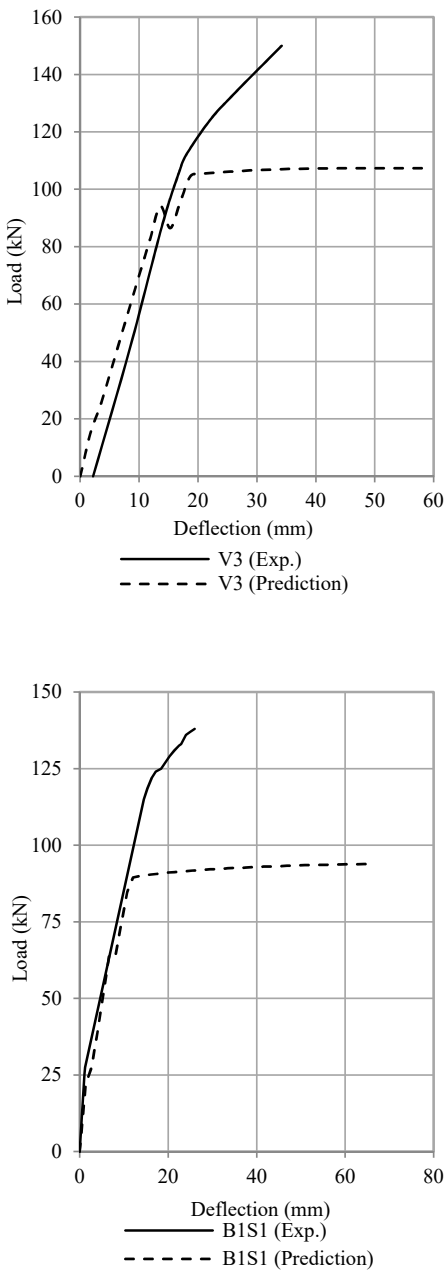

(e)

Figure 20. Comparison of the debonding load between the experimental results and the prediction (Type 2. debonding failure occurs before the yielding of tensile reinforcement) (a) Spadea et al. [3], (b) Shehata et al. [5], (c) Benjeddou et al. [12], (d) Kotynia et al. [13], and (e) Fu et al. [17].

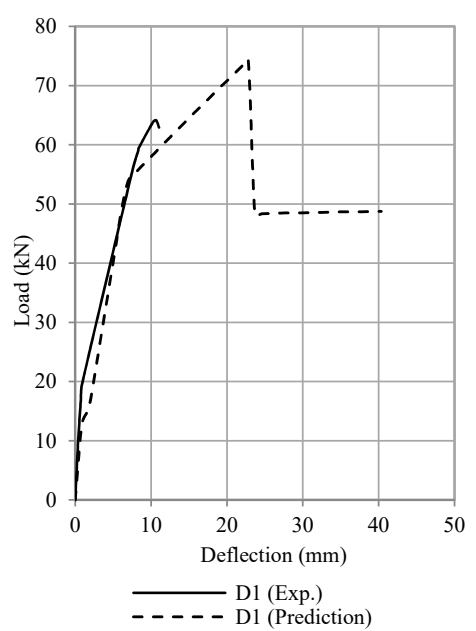

(a)

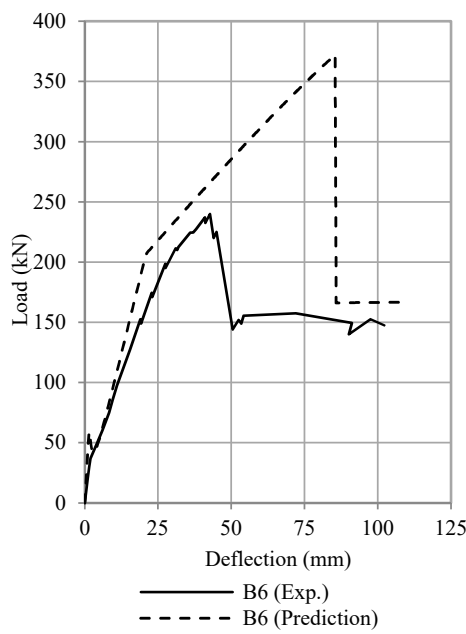

(b)

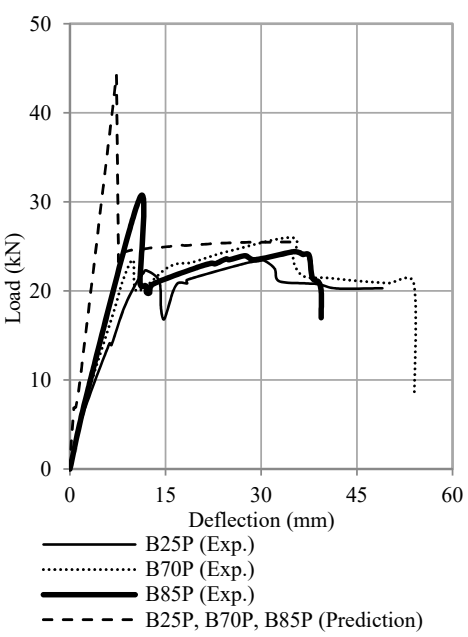

(c)

Figure 21. Cont. 

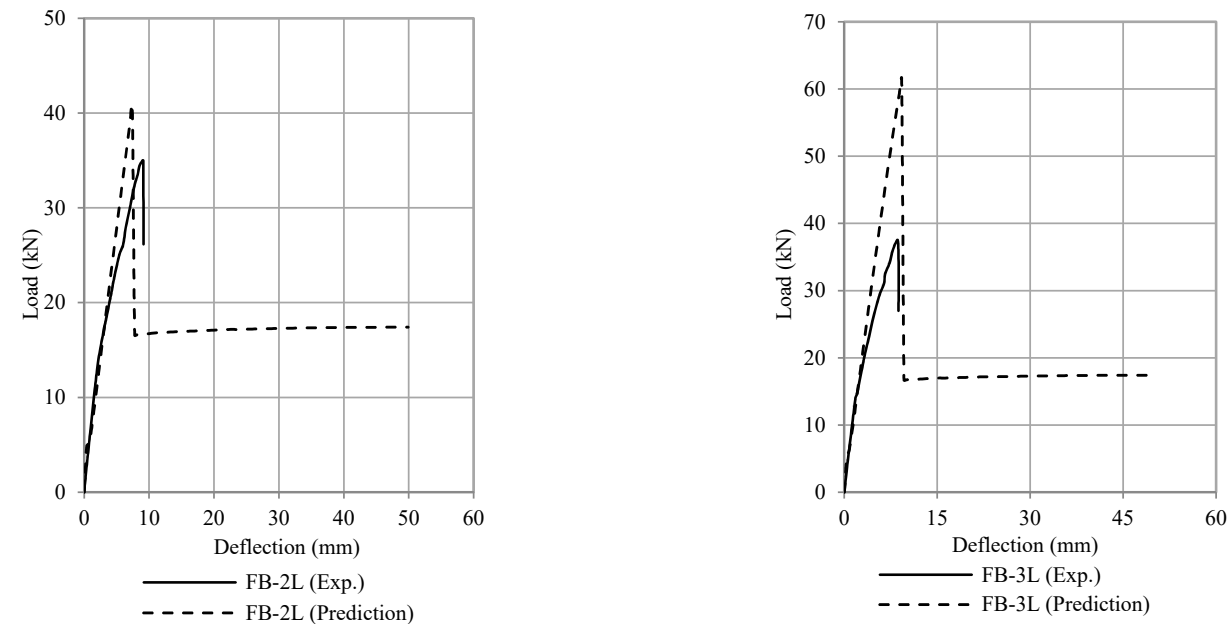

(d)

Figure 21. Comparison of the debonding load between the experimental results and the prediction (Type 3. debonding failure value is higher than the experimental debonding load) (a) Brena et al. [8], (b) Khomwan et al. [11], (c) Al-Tamimi et al. [14], and (d) Ahmed et al. [15].

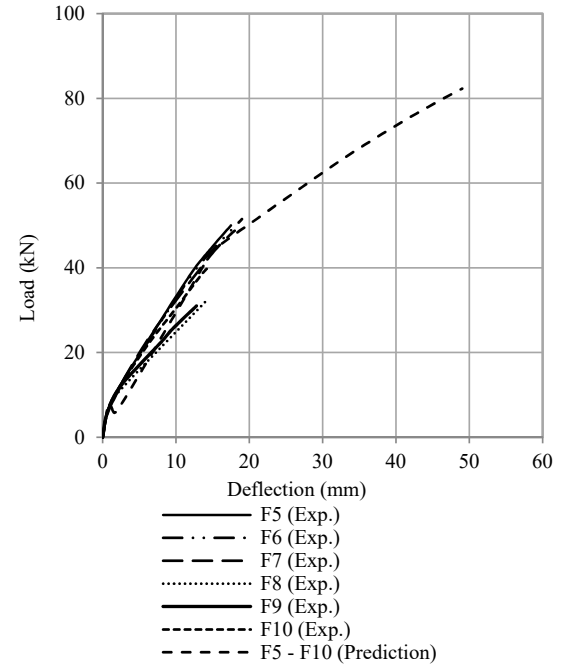

(a)

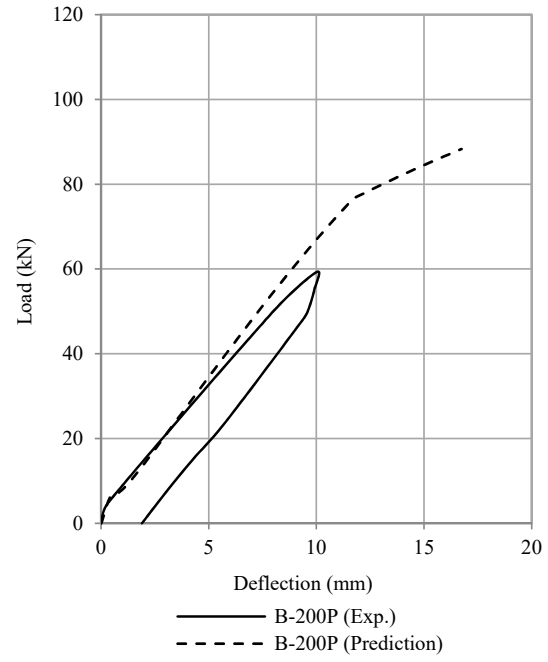

(b)

Figure 22. Comparison of the debonding load between the experimental results and the prediction (Type 4. the value of the calculated debonding moment is higher than the ultimate nominal moment of the cross-section) (a) Fanning and Kelly [7], and (b) Pimanmas et al. [10].

The comparison between analytical prediction and experimental data show a considerable variation due to several factors, including the bond behavior between the FRP plates and concrete, which is not the same in every case reviewed in this study; this is not the scope included in this study. The constant $\omega$ was then adjusted to obtain the value that represents all data. Figures 19 and 20 show conservative predictions using the value of $\omega=6$. However, this value does not give a conservative prediction for the other experimental data, as shown in Figures 21 and 22. From the comparison results shown above, it can be concluded that the value of $\omega=6$ will give a less conservative value. Therefore, the author recommends a value between 5 and 6 to provide a conservative value. A value of $\omega$ lower than 5 will result in a too conservative value, and most of the capacity of the CFRP plate to carry the load is unused. On the other hand, a value of $\omega$ greater than 6 will result in a high debonding moment value, which means not safe. 


\section{Conclusions}

Bending capacity and debonding load of six reinforced concrete beams with and without CFRP plates were measured and the results were combined with an extensive dataset drawn from the existing literature. These data were used to construct a predictive mathematical model for debonding moments. Results from this model were then compared with the bending capacity of the beam with the different tensile reinforcement ratios from the experimental test results and previously proposed models. The following conclusions are drawn.

Reinforced concrete beams strengthened with CFRP plate have a 10\% to 50\% higher flexural capacity than unplated beams depending on the value of the tensile reinforcement ratio.

Failures in reinforced concrete beams with small reinforcement ratios (1\% and $1.5 \%)$ are debonding failures due to the delamination of CFRP plates. In reinforced concrete beams with a reinforcement ratio of $2.5 \%$, flexural failure occurs without delamination on the CFRP plate. These results indicate that an increase in the tensile reinforcement ratio causes a reduction in the stress on the CFRP plate.

The ratio of tensile reinforcement, plate thickness, the ratio of modulus of elasticity of concrete, and the modulus of elasticity of the plate all affect the debonding load of reinforced concrete beam strengthened with the CFRP plate at the bottom of the beam.

The fiber element method predicts the response of reinforced concrete sections with CFRP plates with a high degree of accuracy. The debonding load calculated using the proposed model compares conservatively to the experimental value.

Due to safety considerations and optimization of the capacity of the CFRP plate to carry the load, the value of $\omega$ in Equation (11) is proposed to be between 5 and 6.

Author Contributions: R.T. and S.D. analyzed the experimental data and literature data, fiber element and finite element analysis, writing, and editing; R.T. and Z.Z. performed the experiments; S.D. reviewed and revised the manuscript. All authors have read and agreed to the published version of the manuscript.

Funding: This research was funded by Penelitian Dasar Unggulan Klaster Riset-Publikasi ke Guru Besar Universitas Andalas (PDU-KRP2GB-Unand) for the 2019 fiscal year, with the contract number T/15/UN.16.17/PP.IS-KRP2GB/LPPM/2019.

Institutional Review Board Statement: Not applicable.

Informed Consent Statement: Not applicable.

Data Availability Statement: Data is contained within the article.

Acknowledgments: The authors would like to thank PT. Fyfe Fibrewrap Indonesia for material support and installation of CFRP plates.

Conflicts of Interest: The authors declare no conflict of interest.

\section{References}

1. Thamrin, R.; Zaidir; Zakiyyah, A. Effect of reinforcement ratio on flexural behavior of reinforced concrete beams strengthened with CFRP plates. IOP Conf. Ser. Earth Environ. Sci. 2021, 708, 012015. [CrossRef]

2. Garden, H.N.; Hollaway, L.C. An experimental study of the influence of plate end anchorage of carbon fibre composite plates used to strengthen reinforced concrete beams. Compos. Struct. 1998, 42, 175-188. [CrossRef]

3. Spadea, G.; Bencardino, F.; Swamy, R.N. Structural Behavior of Composite RC Beams with Externally Bonded CFRP. J. Compos. Constr. 1998, 2, 132-137. [CrossRef]

4. Ross, C.A.; Jerome, D.M.; Tedesco, J.W.; Hughes, M.L. Strengthening of reinforced concrete beams with externally bonded composite laminates. Struct. J. 1999, 96, 212-220.

5. Shehata, I.A.E.M.; Cerqueira, E.C.; Pinto, C.T.M. Strengthening of RC beams in flexure and shear using. In Proceedings of the 5th International Conference on Fibre-Reinforced Plastics for Reinforced Concrete Structures, Cambridge, UK, 16-18 July 2001; Volume 1, pp. 97-106.

6. Nguyen, D.M.; Chan, T.K.; Cheong, H.K. Brittle Failure and Bond Development Length of CFRP-Concrete Beams. J. Compos. Constr. 2001, 5, 12-17. [CrossRef] 
7. Fanning, P.J.; Kelly, O. Ultimate Response of RC Beams Strengthened with CFRP Plates. J. Compos. Constr. 2001, 5, 122-127. [CrossRef]

8. Brena, S.F.; Bramblett, R.M.; Wood, S.L.; Kreger, M.E. Increasing Flexural Capacity of Reinforced Concrete Beams Using Carbon Fiber-Reinforced Polymer Composites. ACI Struct. J. 2003, 100, 36-46. [CrossRef]

9. Breña, S.F.; Macri, B.M. Effect of Carbon-Fiber-Reinforced Polymer Laminate Configuration on the Behavior of Strengthened Reinforced Concrete Beams. J. Compos. Constr. 2004, 8, 229-240. [CrossRef]

10. Pimanmas, A.; Pornpongsaroj, P. Peeling behaviour of reinforced concrete beams strengthened with CFRP plates under various end restraint conditions. Mag. Concr. Res. 2004, 56, 73-81. [CrossRef]

11. Khomwan, N.; Foster, S.J.; Smith, S.T. Debonding Failure in CFRP Flexurally Strengthened Reinforced Concrete Beams; The University of New South Wales: Sydney, Australia, 2005; ISBN 85841-407-4.

12. Benjeddou, O.; Ben Ouezdou, M.; Bedday, A. Damaged RC beams repaired by bonding of CFRP laminates. Constr. Build. Mater. 2007, 21, 1301-1310. [CrossRef]

13. Kotynia, R.; Baky, H.A.; Neale, K.W.; Ebead, U.A. Flexural Strengthening of RC Beams with Externally Bonded CFRP Systems: Test Results and 3D Nonlinear FE Analysis. J. Compos. Constr. 2008, 12, 190-201. [CrossRef]

14. Al-Tamimi, A.K.; Hawileh, R.; Abdalla, J.; Rasheed, H.A. Effects of Ratio of CFRP Plate Length to Shear Span and End Anchorage on Flexural Behavior of SCC RC Beams. J. Compos. Constr. 2011, 15, 908-919. [CrossRef]

15. Ahmed, E.; Sobuz, H.R.; Sutan, N.M. Flexural performance of CFRP strengthened RC beams with different degrees of strengthening schemes. Int. J. Phys. Sci. 2011, 6, 2229-2238. [CrossRef]

16. Bilotta, A.; Ceroni, F.; Nigro, E.; Pecce, M. Efficiency of CFRP NSM strips and EBR plates for flexural strengthening of RC beams and loading pattern influence. Compos. Struct. 2015, 124, 163-175. [CrossRef]

17. Fu, B.; Chen, G.M.; Teng, J.G. Mitigation of intermediate crack debonding in FRP-plated RC beams using FRP U-jackets. Compos. Struct. 2017, 176, 883-897. [CrossRef]

18. $\mathrm{Wu}, \mathrm{Z}$; $\mathrm{Wu}, \mathrm{Y}$;; Fahmy, M.F. Structures Strengthened with Bonded Composites; Woodhead Publishing: Cambridge, MA, USA, 2020; ISBN 978-0-12-821089-5.

19. Mansour, W.N. Analysis of RC Continuous Beams Strengthened in Flexure with FRP Using FEM. Available online: https: //www.researchgate.net/profile/Walid-Mansour/publication (accessed on 18 May 2020).

20. Motavalli, M.; Czaderski, C.; Pfyl-Lang, K. Prestressed CFRP for Strengthening of Reinforced Concrete Structures: Recent Developments at Empa, Switzerland. J. Compos. Constr. 2011, 15, 194-205. [CrossRef]

21. Oehlers, D.J. Reinforced Concrete Beams with Plates Glued to their Soffits. J. Struct. Eng. 1992, 118, 2023-2038. [CrossRef]

22. Teng, J.G.; Chen, J.F. Debonding failures of RC beams strengthened with externally bonded FRP reinforcement: Behaviour and modelling. In Proceedings of the First Asia-Pacific Conference on FRP in Structures (APFIS 2007), Hong Kong, China, 12-14 December 2007; pp. 12-14.

23. Thamrin, R.; Sari, R.P. Flexural Capacity of Strengthened Reinforced Concrete Beams with Web Bonded Steel Plates. Procedia Eng. 2017, 171, 1129-1136. [CrossRef]

24. Thamrin, R. Effect of Strengthening Method and Anchorage Length on Flexural Capacity of RC Beams with Steel Plates. J. Eng. Sci. Technol. 2018, 13, 3781-3794.

25. Thamrin, R. Analytical Prediction on Flexural Response of RC Beams Strengthened with Steel Plates. In Proceedings of the MATEC Web of Conferences: International Symposium on Civil and Environmental Engineering (ISCEE), Wuhan, China, 20-21 December 2016; EDP Sciences: Les Ulis, France, 2017; Volume 103, p. 2012.

26. Mander, J.B.; Priestley, M.J.N.; Park, R. Theoretical Stress-Strain Model for Confined Concrete. J. Struct. Eng. 1988, 114, 1804-1826. [CrossRef]

27. Cervenka, V.; Jendele, L.; Cervenka, J. ATENA Program Documentation-Part 1: Theory. Available online: https://www.cervenka. $\mathrm{cz} /$ products/atena/documentation (accessed on 11 March 2020). 